\title{
El Camarín de San Diego y su geometría simbólica
}

M. ALEJANDRO SIFUENTES

CON LA COLABORACIÓN DE: JOSÉ LUIS GARCIAA R. MIGUEL MARTÍN DEL CAMPO

Centro de Ciencias del Diseño y la Construcción/UAA

"... y fue construido por un indigena de Lagos cuyo nombre debía conservarse, si la ignorancia y la ingratitud supieran admirar el genio".

Agustín R. González.

\section{INTRODUCCIÓN}

Sobre una de las puertas de las escuelas de Platón se hallaba escrito un precepto universal entre los antiguos: "No entre el que ignore la Geometría". Si hemos de atender a las propias expresiones que la misma gente de Aguascalientes tenía en el pasado sobre su arquitectura, entre las múltiples muestras de admiración y arrebato, las que se externaban en torno al Camarín del Templo de San Diego ocupan un lugar indiscutible. En efecto, fuera por la devoción religiosa de sus habitantes, fuera por la sabiduría erudita de los notables, lo cierto es que al Camarín se le consideraba una de las más bellas joyas arquitectónicas de Aguascalientes. Y no les faltaba razón, ni exageraban. Una de las constantes más llamativas entre las diversas opiniones de doctos y neófitos era precisamente la hermosura de este extraordinario recinto. Ahí comenzó nuestra aventura.

¿Cómo superar el nivel de las opiniones -románticas las más de las veces, si bien no ausentes de sustento- para alcanzar a ex- 
plicar en dónde residía y en qué consistía la belleza, aceptada sin discusión por todos, del "suntuoso" Camarín de la Virgen? La geometría, sin duda, nos proporcionaba un amplio y generoso campo de experimentación y la posibilidad de la explicación científica y rigurosa de ese atributo tan inasible y a la vez manoseado de belle$z a$. Pero, al mismo tiempo, la geometría no sería nada sin la explicitación de su simbolismo y de su asociación con contenidos religiosos, particularmente los vigentes en el período novohispano. Por ello, la aventura hacia la geometría del Camarín necesariamente nos conducía a la iconología, y ambas al conjunto de ideas, creencias, simbolismos y condiciones materiales de la sociedad novohispana, tanto en un orden general como en el particular referido al campo de la edificación. Encontrar el patrón o estructura racional de proporcionamiento armónico detrás de la belleza del monumento era el primer reto. Incrustarlo después dentro de las condiciones históricas específicas de su producción, para dar cuenta del objeto arquitectónico como un producto cultural total y significativo, constituyó el segundo desafío.

El asunto se presentaba como un problema de estrategia, en el sentido de que obligaba la utilización de medios gráficos para la validación de la hipótesis que sobre el particular habíamos elaborado. Pero la develación de aquella estructura, oculta detrás de la belleza del Camarín, corría el grave riesgo de perderse entre la hipóstasis de la geometría per se, si se desligaba de su sentido trascendente, simbólico. Como tendremos oportunidad de mostrar en las conclusiones del estudio, el Camarín de San Diego constituye un monumento extraordinario no sólo por ser probablemente uno de los últimos de su tipo, sino por su concepción misma, por la idea y los principios fundamentales de orden simbólico que su constructor supo plasmar a través de un sistema de proporción octagénico y dinérgico, sólo explicables por las condiciones del mundo novohispano. El Camarín de San Diego se concibió con una geometría todavía euclidiana, una geometría del "mundo vivido", tras- 
cendental y por ello mismo simbólica, ${ }^{1}$ en un momento en que las geometrías no euclidianas (por lo general desdeñosas de esta dimensión trascendente) luchaban por la supremacía contra los residuos de una geometría simbólica en Europa, y en un momento en el que las condiciones impuestas por las reformas de la Casa de los Borbones no propiciaban el uso en la Nueva España de geometrías mito-poéticas o metafísicas. De ahí la importancia de la relación entre la geometría y el simbolismo religioso en el Camarín, que conforman una unidad sólo escindible parcialmente por necesidades del análisis y para fines estrictamente didácticos.

Y es precisamente esa concepción trascendente, en pleno auge neoclásico, lo que hace al monumento único entre los edificios religiosos de su tiempo. Santiago Medina, su constructor, supo armonizar cierto academicismo con preceptos barrocos, es decir, supo echar mano de una suerte de ars combinatoria, muy propia del barroco europeo, por la cual se conciliaban, en una síntesis asombrosa, oposiciones esenciales: fundamentalmente las esferas perceptual (el dinamismo sensual barroco) y conceptual (la claridad racional neoclásica), ${ }^{2}$ pero siempre sobre la base de esa geometría simbólica, en perfecta unión con la propia realidad vivida por la sociedad novohispana, cuya dimensión religiosa en Aguascalientes resulta indiscutible.

\section{¿UN BARROCO REGIONAL?}

La arquitectura religiosa de la segunda mitad del siglo XVIII, en la región, posee indudables rasgos comunes que nos inducen a pensar en la existencia de una misma fuente o tradición en la que las formas barrocas abrevaron. Desde luego, no se trata sólo de las ca-

1. Cfr. el excelente estudio de Alberto Pérez Gómez, La Génesis y Superación del Funcionalismo en Arquitectura, Ed. Limusa, México, 1980.

2. Ibid., pp. 166-171. 
racterísticas climáticas y topográficas de la zona, o de los materiales de construcción, sino del surgimiento y definición de ciertas características plásticas que aplicaron y desarrollaron los diversos maestros y artífices que pulularon por la región. Uno de los rasgos más acusados en todo el centro y el norte novohispanos, no privativo de la zona pero sí muy evidente, fue el del constante movimiento de maestros de un lado a otro de los más importantes centros urbanos de esta región, ${ }^{3}$ particularmente entre los actuales estados de Guanajuato, San Luis Potosí, Aguascalientes, Zacatecas, Jalisco, y Durango. Varios de los maestros trashumantes provenían de la ciudad de México o de Querétaro, otros de la ciudad de Guadalajara, pero fue en esos lugares en donde desarrollaron niveles de expresión artística que diferenciaron el carácter de la escultura y la arquitectura del resto de las edificaciones del territorio novohispano. En el caso que nos ocupa, desde Guanajuato hasta Aguascalientes, pasando por el punto intermedio de Lagos de Moreno y el más alejado de San Luis Potosí, obsérvase la misma veta de artífices aproximadamente a partir de 1747, año en que se establece en Aguascalientes un personaje fundamental para comprender el desarrollo de las formas barrocas en toda la región: Felipe de Ureña. Bajo su escuela pueden agruparse varios maestros que trabajaron en el bajío guanajuatense y en sus puntos extremos, por los cuatro rumbos.

El templo franciscano de San Diego, el templo de la Compañía, la Parroquia y la Valenciana, por citar sólo algunos de la ciudad de Guanajuato; las Parroquias de Lagos de Moreno y San Juan de los Lagos en el estado de Jalisco; el Real del Catorce y la ciudad de San Luis Potosí en el estado del mismo nombre; así como el Encino, Guadalupe, la Merced, San Marcos, el Palacio de Gobierno, el actual Centro de Artes Visuales, el Camarín de San Diego, en la

3. Ver el excelente estudio de Clara Bargellini, La Arquitectura de la Plata. Iglesias Monumentales del Centro-Norte de México, 1640-1750, IIE-UNAM, México, 1991, pp. 53-76 
ciudad de Aguascalientes; son monumentos que atestiguan, por sus rasgos específicos, la huella de la mano o la escuela de Felipe de Ureña, caracterizada por el uso del estípite poco ornamentado, más bien plano, de líneas geométricas claras, contrastadas con suaves molduras onduladas, rematadas por roleos y volutas, integrando círculos esotéricos, rocallas, guardamalletas, borlas y cortinajes en sus cuerpos y en los interestípites mismos. De este modo, Felipe de Ureña -y su escuela- aparece como el gran difusor de las formas del barroco estípite en la región del Bajío y ciudades y villas circunvecinas, ${ }^{4}$ por lo que es perfectamente lícito hablar de un barroco plenamente identificado en la comarca en la que se encontraba Aguascalientes en el período novohispano.

\section{Felipe de Ureña en Aguascalientes}

Nacido en 1697 y natural de Toluca, Felipe de Ureña era miembro de una familia de artesanos de cierta importancia en el centro de la Nueva España. Con toda probabilidad nuestro personaje debió haber aprendido el oficio de la hechura y ensamblaje de retablos con su propio padre, Hipólito, compartiendo su aprendizaje con sus hermanos José y Carlos, así como con su primo Juan Bernabé de Ureña. ${ }^{5}$ Se tiene noticia de un homónimo de Felipe de Ureña y de otros individuos con el mismo apellido trabajando en la ciudad de México y en la jurisdicción de San José de Toluca, ${ }^{6}$ así como de dos hermanas, Petra y Francisca -esta última esposa de Juan García

4. Ver Alfonso Reséndiz G., "El taller de Felipe de Ureña en Aguascalientes y la difusión del Barroco Estípite en la región", en III Certamen Histórico-Literario, Archivo Histórico del Estado de Aguascalientes, Ayuntamiento de Aguascalientes, 1993.

5. Ibid., p. 23.

6. Trátase de Juan Ignacio de Ureña en el primer caso, y de Francisco de Ureña en el segundo. Cfr. Glorinela González Franco, et. al., Catálogo de Artistas y Artesanos de México, INAH, México, 1986, pp. 98 y 241-242. 
López de Castañeda, socio de Felipe de Ureña- ubicadas en Aguascalientes, 'además de otros parientes aún no del todo identificados. En San José de Toluca se ubica también a Juan de Ureña, pero desconocemos si se trata del primo citado o de otro personaje.

Según las informaciones de que disponemos, Felipe de Ureña comenzó su oficio desde temprana edad en Toluca, y al parecer comenzaba a ser conocido y requerido para trabajos de cierta relevancia. En 1729 José Cillero, "entendido en Arquitectura", a la sazón guardián del Convento de la Asunción de Toluca, aprovechó la habilidad artística de nuestro personaje para erigir la sacristía y sus retablos (hoy perdidos), siendo quizá, como dice Villegas, "la primera y más completa obra churrigueresca, únicamente compuesta de apoyos estípites". ${ }^{8}$ De acuerdo con noticias proporcionadas por este autor, de Ureña estuvo incluso trabajando desde 1726, cuando realizó el aldabón de las puertas laterales de la Tercera Orden de Toluca, por lo que "era conocido ya como arquitecto", y por tanto "tenía muchos años de preparación artesanal anteriores a la llegada de Jerónimo de Balbás". ${ }^{9}$ Incluso en su firma Ureña se ostentaba como "Maestro mayor de Arquitectura". ${ }^{10}$

Alfonso Reséndiz, por su parte, señala que en 1739 se activa el taller de Felipe de Ureña y que ya para entonces "había adquirido un gran prestigio como escultor y ensamblador", "fama quizá debida a su intervención en la sacristía toluqueña diez años antes, lo que abre el punto de discusión sobre la primacía del uso del estípite entre de Ureña y Jerónimo de Balbás, un punto de debate no liquidado del todo, pero cuya dilucidación rebasa los propósitos del presente artículo.

7. AHEA, Fondo de Protocolos Notariales, Caja 16, Exp. 7, Escr. 28, F. 43v-44v, Caja 17, Exp. 9, Escr. 17, F. 32v-33v, y Caja 18, Exp. 7, Escr. 9, F. 14v-15v.

8. Cfr. Víctor Manuel Villegas, Valenciana y el Churrigueresco, edición del autor y la Universidad de Guanajuato, México, 1989, p. 170.

9. Ibid. (las cursivas son nuestras).

10. Ibid., p. 172.

11. Cfr. Alfonso Reséndiz, Op. cit., p. 23.

12 C A A 
Sea lo que fuere, lo cierto es que al cabo de un tiempo de Ureña se trasladó a la ciudad de México estableciendo su taller en forma, el cual funcionó desde 1733 hasta 1747, año en que se desplazó a la villa de Aguascalientes. En el lapso comprendido entre 1737-1738, según Reséndiz, de Ureña fue colaborador de Balbás, por lo que cabe afirmar que, al margen de si utilizó el estípite antes o después de Balbás, con éste se consolidó aquél, en la moda churriguera.

Bien establecido con su propio taller, a de Ureña comienzan a llegarle contratos para ornar con retablos múltiples templos de diversas órdenes religiosas y del clero diocesano. Contrata retablos mayores y colaterales y obras de arquitectura indistintamente para los franciscanos, los ermitaños de San Agustín, los carmelitas, los jesuitas y los mercedarios, mientras que hace lo propio para el clero secular en conventos y parroquias en varias ciudades circunvecinas a la ciudad de México. En el año de 1742 se le solicita la construcción del retablo mayor de la Parroquia de Aguascalientes, encargando su ensamblaje a su yerno Juan García López de Castañeda, con quien formó sociedad desde 1744 hasta 1750, dándole incluso poder a éste para firmar contratos en su nombre. Es precisamente este último quien realiza en 1744 el contrato respectivo luego de que el retablo, debidamente diseñado y fabricado en sus partes, fue trasladado de la ciudad de México hasta Aguascalientes "en ciento un cajones de mulas bien acondicionadas". ${ }^{2}$

La circunstancia -fortuita bajo ciertos aspectos- del exceso de trabajo y, por ende, el incumplimiento de algunos contratos, o bien deudas contraídas, pudieron ser la causa de la determinación de Felipe de Ureña para trasladarse a la villa de Aguascalientes, en donde instala su taller por la calle de Tacuba (hoy 5 de Mayo) con su yerno Juan García de Castañeda. El establecimiento del maestro "trashumante", como lo llama Tovar de Teresa, en Aguascalientes

12. Ibid., pp. 19 y 24. 
debióse también a los buenos oficios del Dr. Colón de Larreategui, con quien de Ureña tuvo buenos contactos. Por lo demás, la villita de la Asunción experimentaba por aquel entonces un auge importante. En este sentido, no puede soslayarse el hecho, harto significativo, del desplazamiento del control político, económico y religioso del campo a la ciudad, que es quizá, según Reséndiz, "uno de los acontecimientos más notables de la época Barroca novohispana". En el caso de la villa, tal circunstancia determinó que en términos de la riqueza agrícola y comercial Aguascalientes superara a Santa María de los Lagos y otras poblaciones aledañas. La importancia de Aguascalientes en la región y su localización central, entonces, debió atraer a Felipe de Ureña, cuyo taller fue considerado entre los más importantes de la primera mitad del siglo XVIII..$^{13} \mathrm{De}$ aquí salieron retablos mayores y colaterales para el centro y norte de la Nueva España, entre los que cabe destacar los encargos para la Parroquia de Zacatecas, para la Catedral de Durango y para Sombrerete, por citar sólo algunos.

De la notable estancia de la familia de Ureña en Aguascalientes son prueba los numerosos documentos que pueden consultarse en el Archivo Histórico del Estado de Aguascalientes, en donde se encuentran contratos para la realización o conclusión de retablos, movimientos de compra-venta de predios urbanos, compra de esclavos y otros. ${ }^{14}$

\section{LA HERENCIA DE LA ESCUELA DE UREÑA.}

Para $1756^{15}$ Felipe de Ureña se instala en la ciudad de Guanajuato, a donde había sido llamado desde 1750 para la continuación del

13. Ibid., pp. 14-15.

14. AHEA, FPN, particularmente los años comprendidos entre 1747 y 1756 , en donde se pueden encontrar expedientes referidos a Felipe de Ureña.

15. Reséndiz, Op. cit., p. 26. 
Templo de la Compañía, que había iniciado el bethlemita Fray Joseph de la Cruz, no obstante que la primera prueba documental de su presencia en Guanajuato data de $1764 .{ }^{16} \mathrm{El}$ templo fue concluido en 1765, y en él Felipe de Ureña consumó su calidad de Maestro de Arquitectura y dejó plenamente establecidos los rasgos de la escuela que tanta influencia dejó en toda el área. En la Compañía las formas del retablo con estípites irrumpen en su grandiosa portada por primera vez en la región; a partir de aquí, la arquitectura "ureñana" se desparramó con generosidad gracias, entre otras cosas, a la continuidad de la tradición en la persona de Francisco Bruno de Ureña, hijo del maestro, a quien se debe la difusión de la escuela de su padre. A este personaje se le ubica en Guanajuato, en donde interviene en el "Reconocimiento y vista de ojos" del Templo franciscano de San Diego, en el año de $1772 .{ }^{17}$ De hecho, como lo sugiere Tovar de Teresa, ${ }^{18}$ no es improbable que Francisco Bruno haya tenido que ver directa o indirectamente en la fábrica del Santuario de Guadalupe en la villa de Aguascalientes, pues las formas del barroco estípite de su portada son muy semejantes a las de la portada de San Diego de Guanajuato. Lo que sí puede afirmarse es que definitivamente se trata de la misma factura, si no es que de la misma mano.

Por fin, Felipe de Ureña muere en Guanajuato en 1777. A partir del establecimiento de su taller en Aguascalientes y de su estancia en Guanajuato, su influencia caló por toda la región centro y sus seguidores trabajaron y fueron fieles a la tradición hasta bien entrado el siglo XVIII, como lo demuestran las huellas de múltiples edificios en los que se encuentra el sello formal que identifica la

16. Cfr. Isauro Rionda A., et. al., El Oratorio Filipense en Guanajuato. 200 años y los precursores Jesuitas, Ediciones Estudio 54, México, 1994, pp. 35-36.

17. Municipio de Guanajuato, Catálogo de Bienes Inmuebles de Propiedad Federal, México, 1976, p. 110.

18. En entrevista para Canal 6, durante su corta estancia en Aguascalientes en 1993. 
huella de Ureña: el círculo apendicular o esotérico documentado por Villegas, así como las guardamalletas, las que, según este autor, fueron utilizadas por él antes que Lorenzo Rodríguez y que el propio Balbás, quien jamás las utilizó. ${ }^{19} \mathrm{El}$ fruto de la escuela de Ureña puede observarse en Aguascalientes en gentes como Gregorio Reyes y Santiago Medina, alarife del Camarín de San Diego.

"SI LA IGNORANCIA Y LA INGRATITUD SUPIERAN ADMIRAR EL GENIO": noticias SObRe Santiago Medina, aLARIFE

¿Quién fue Santiago Medina? ¿Cuál fue su contribución exacta en la edificación del hermoso Camarín de San Diego? ¿Tal era su nombre? Las noticias sobre este personaje, a diferencia de las que disponemos para el caso de Juan Francisco Calera, benefactor material de la magna obra, son extraordinariamente fragmentarias. Incluso se ha escatimado su autoría en el diseño del Camarín y se le ha destacado más como un modesto indio alarife, minusvaluando su capacidad y las enseñanzas que poco a poco fue asimilando, provenientes de dos tradiciones aparentemente encontradas. En efecto, las evidencias disponibles nos permiten sostener que nuestro alarife encarnó, no sin problemas, la conciliación armónica entre la tradición barroca -que hipotizamos fue en la que se formó, particularmente dentro de la escuela creada por Felipe de Ureña en Guanajuato y en Aguascalientes-, y la tradición académica del neoclásico, que para los años de la construcción del Camarín era ya demasiado fuerte. No es improbable que el aprendizaje de Medina haya tenido lugar en algún taller de alguno de los discípulos de Ureña o de Francisco Bruno, su hijo, y tampoco es improbable que ya en su madurez haya sentido y asimilado las enseñanzas de Francisco Eduardo Tresguerras, a juzgar por su pretendido lugar de origen,

19. Ver Víctor Manuel Villegas, Valenciana..., Op. cit., p. 171. 
la villa de Lagos, una región en la que se dejó sentir con hondura tanto la influencia de Ureña como de Tresguerras. Ochoa señala respecto al alarife:

Por ninguna parte hemos encontrado documento que acuse el nombre del ar-
quitecto del dicho Camarín (...) la tradición lo concede al famoso arquitecto
del siglo xviI, don Francisco Eduardo Tresguerras, habiendo quienes le con-
ceden sólo la paternidad de planos y dibujos, esto es, la parte intelectual y la
directa ejecución del ciprés Nicho de la Purísima y del cimborrio, la ma-
jestad de su cúpula. Hay quien lo atribuye a Tolsá, Manuel, de la misma épo-
ca de Tresguerras. Los historiadores de Aguascalientes nos afirman que la
construcción del Camarín es de un indio de Lagos, pero cuyo nombre ha
quedado ignorado. ${ }^{20}$

Cuando Ochoa dice "ignorado", se refiere no a que se desconozca el nombre del constructor, sino al hecho de que no se le ha dado su valor frente a los gigantes que de acuerdo con los historiadores de hecho o de derecho le disputan su autoría. Para nosotros es concluyente la inscripción que aparece en una de los pilastras del pasillo izquierdo que da al Camarín, y que a la letra dice:

"El Mtro. S.tiago MEdina DElineo y Construio este Templo a MARIA SSma Ntra Sa a expensas del Caudal del S. Cptn Dn JuN Franco Calera."

Como se sabe, en el argot de la época "delinear" era equivalente a proyectar o diseñar, por lo tanto, al delinear y construir el Camarín, Medina no hace sino dejar testimonio de su autoría total en la obra, sin demérito alguno de las influencias que pudo haber recibido de Tresguerras, por ejemplo. Es poco probable que Tolsá haya tenido que ver con la edificación, entre otras cosas porque llegó a la Nueva España en diciembre de 1791, nueve meses antes de que comenzara la construcción del Camarín, y porque además de inmediato recibe encargos que lo mantienen no sólo ocupadísimo, sino

20. Angel S. Ochoa V. Breve Historia de la Purísima de San Diego de Aguascalientes, Gobierno Eclesiástico del Obispado de Aguascalientes, 1953, p. 32. 
confinado en la ciudad de México o en las villas o ciudades importantes a su alrededor. Es más probable, por el contrario, que Medina haya conocido a Tresguerras directamente 0 cuando menos su obra. ${ }^{21}$ Respecto al arquitecto celayense, éste tenía por costumbre anotar cuidadosamente todos los trabajos que hacía, y dado que en las relaciones de sus obras no se menciona ni un sólo dato respecto a trabajos realizados en o para Aguascalientes, ${ }^{22}$ así fuera de diseño o de obra material, es poco factible que haya tenido intervención alguna en el Camarín, a no ser a través de la influencia que muy probablemente tuvo en Santiago Medina. Por lo demás, sabemos que Tresguerras, aunque produjo algunas obras barrocas, cuando hubo adoptado el neoclásico lo hizo de una manera categórica que no deja dudas sobre la imposibilidad de que hubiera aceptado, en una época tan tardía como la de la construcción del Camarín (1792-1797), ver conjugadas estas dos tradiciones en el monumento.

Por otra parte, ha quedado plenamente comprobado que el personaje llamado "Nicolás de Santiago", "Nicolás de Santiago Medina" o bien "Nicolás Antonio Santiago de Medina" es el mismo que Santiago Medina, tal como lo prueba el documento que localizamos en el Fondo Judicial Civil del Archivo Histórico del Estado de Aguascalientes, del año de 1777, en un expediente relativo a un litigio sobre bienes de la esposa de Pedro Manuel Calera, hermano de Juan Francisco, benefactor del Camarín, y en el que se solicita el parecer del "Mtro. Alarife" como "abaluador" de uno de los bienes inmuebles objeto del pleito. ${ }^{23} \mathrm{El}$ documento prueba además que la relación entre el alarife y la familia Calera databa de tiempo atrás, sin contar que lo confirma como un maestro establecido y con

21. Cfr. Israel Katzman, Arquitectura del siglo XIX en México, Centro de Investigaciones Arquitectónicas, UNAM, México, 1973, pp. 295-300, quien proporciona datos biográficos y de obras tanto de Tolsá como de Tresguerras.

22. Relaciones de las que Katzman da una amplia información.

23. AHEA, Fondo Judicial Civil, Exp. 17.3, F.23f. 
algún prestigio o posición dentro de la sociedad aquicalidense, no obstante su pretendido origen indígena. De esta manera, pues, se le puede ubicar con precisión en Aguascalientes desde 1770, en donde no es improbable que haya tenido contacto o conocimiento del taller de los discípulos del difunto Juan García de Castañeda (muerto en 1763), ${ }^{24}$ yerno de Felipe de Ureña. Este hecho es demasiado importante para soslayarlo; en efecto, lo anterior sugiere que Santiago Medina debió ser influido por la escuela de Ureña a partir de su taller en Aguascalientes, y que más tarde pudo haber aprendido recursos estilísticos -sobre todo en la escultura arquitectónica y en la geometría- provenientes de la avasalladora fuerza de Tresguerras; sólo así se explica la presencia de los cuatro retablos barrocos, guardamalletas y un par de estípites ureñanos en una obra cuasi neoclásica o cuando menos en transición hacia él: la del Camarín.

Tres escrituras más nos proporcionan otros elementos. La primera de ellas refiere una compra-venta que se efectúa en el año de 1770 entre Don Matías Hernández como vendedor, y "Nicolás Antonio Santiago" como comprador, a quien se hace alusión como "vesino asimismo de esta dha Villa" (de Aguascalientes), quien adquiere un pedazo de tierra de 12 varas de frente de oriente a poniente y 25 de norte a sur, "cuya tierra es la misma en que el comprador tiene fabricada la casa de su morada" ${ }^{25}$ Más tarde, en el año de 1771, volvemos a encontrar a este personaje en una operación de arrendamiento de "un pedazo de tierra de pan llevar (...) en términos de esta dha Villa", entre Don Manuel Rafael de Aguilera como apoderado de Juan José de Aguilera y "Nicolás Antonio de Medina" y Félix Alejandro Prieto (arrendatarios), "ambos vesinos de esta dha Villa". El tercer documento es del año de 1787, y corresponde a la compra-venta de "una casa baja de terrado" que se ubi-

24. El testamento en AHEA, FPN, Caja 22, Exp. 4, Escritura 9, F. 27f-28f.

25. AHEA, FPN, Caja 84, Exp. 6, Escritura 17, F. 22v-24f. 
ca en el mismo predio de la primera escritura indicada, siendo sus contratantes "Nicolás Antonio de Santiago Medina" como vendedor y María Josefa Gallegos como compradora, "la qual Casa hiso el Otorgante..." ${ }^{26}$

Varios aspectos pueden señalarse de estos tres documentos: que por lo menos un tiempo Santiago Medina radicó de fijo en Aguascalientes y que, aunque en estos expedientes no se mencione su oficio, la expresión en cursivas ("la qual Casa hiso...") es una clara referencia a su calidad de alarife.

En los documentos descritos aparece el sujeto con diferentes denominaciones. Hemos comparado las firmas que aparecen en casi todas las escrituras y en ellas, aunque con variantes en el nombre, pueden observarse los mismos rasgos y la misma caligrafía, lo que constituyó un elemento de prueba que nos indujo a pensar que se trata de la misma persona, tal y como quedó demostrado posteriormente, en el curso de la investigación. ${ }^{27}$

\section{RELACIONES ESTILÍSTICO-ARQUITECTÓNICAS ENTRE LAGOS Y AGUASCALIENTES}

La hipótesis de las dos tradiciones formativas de Santiago Medina no implica su mutua exclusión, no obstante que una de las ideas atractivas entre algunos especialistas es la relativa a asociar al alarife, bien con Felipe de Ureña a través de la escuela continuada por el hijo de éste, Francisco Bruno, y por Juan García de Castañeda en el área de Guanajuato y Aguascalientes (Tovar de Teresa), bien con Francisco Eduardo Tresguerras (Ángel Ochoa), o bien directamente con Lagos de Moreno y la construcción de su Parroquia (José de la Vega). La primera versión se sostiene con alguna probabilidad; la segunda con reservas, dado que no hay prueba documen-

26. AHEA, FPN, Caja 29, Exp. 2, Escritura 123, F. 190v-191v (cursivas nuestras).

27. Ver la nota 23. 
tal de la presencia de Tresguerras en Aguascalientes; y la tercera sólo parcialmente, ya que podemos probar con relativa certidumbre que Santiago Medina no fue el constructor de la Parroquia de Lagos, aunque hipotizamos que pudo haber intervenido en la fase terminal de su construcción. Empero, una cosa es incontestable: Aguascalientes y Lagos están estrechamente ligados no sólo por su historia común, sino también por las relaciones estilísticas y arquitectónicas que los ubican como dos de los centros urbanos, de finales del período barroco, que expresaron notable y bellamente la transición al neoclásico. No sería descabellado establecerlos como núcleos de esta transición en el Bajío, con la Parroquia laguense y con el Camarín de San Diego como pivotes precisamente, en ese orden de sucesión en el tiempo.

En relación a esto, Don Francisco de la Maza opinaba que la parroquia laguense marcaba "el fin del barroco mexicano", en donde "se liquida el churrigueresco y comienza el neoclásico", en donde, en fin, "se diluye el barroco en formas agónicas"; después de Lagos, decía Don Francisco, "no queda más camino que el cambio radical de las formas"; para este insigne enamorado de Lagos, su Parroquia y el Santuario de Guadalupe de San Luis Potosí son "las últimas obras del barroco novohispano". Elisa Vargas Lugo, en cambio, califica a la gran iglesia de Lagos como "importante obra de transición entre el fin del churriguera y el principio del neoclásico", aunque más adelante afirma que es "de las últimas grandes construcciones del ultrabarroco", guardando estrechas semejanzas con el barroco guanajuatense, cosa que reafirma Jorge Guerra cuando habla de los "sistemas de Guanajuato", en los que se encuentra Lagos. ${ }^{28}$ Es de señalarse la ausencia de mención alguna al Camarín de San Diego entre los especialistas, lo cual se explica por el imperdonable des-

28. Las citas de De la Maza, Vargas Lugo y Guerra, en Sergio López Mena (compilador), Lagos de Moreno visto y oído, UAM-Atzcapotzalco, México, 1989, pp. 63-64, $65-66$ y 70 , respectivamente. 
conocimiento de esta notable joya y por la ausencia de estudios específicos.

\section{El Camarín de la Purísima Concepción del Templo de San Diego}

Dentro del género de la arquitectura religiosa cristiana se desarrolló en la Nueva España un tipo espacial específico aunque con origen en tradiciones europeas: el camarín, que por lo general se destinaba al ajuar e indumentaria de la Virgen María en alguna de sus advocaciones. El término proviene del latín camara y éste a su vez

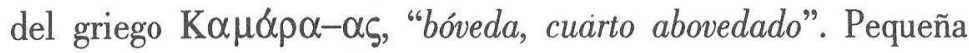
habitación destinada al arreglo de la imagen principal y a conservar sus joyas y ornamentos, situada detrás del altar. Posee una especie de nicho abierto y elevado, colocado junto al muro del fondo del altar o en el ábside. ${ }^{29}$

La relativa escasez de edificios de esta naturaleza y su distinta ubicación en el tiempo y en el espacio impiden ser categóricos en relación al desarrollo del género, pero la mayoría de ellos son dieciochescos -salvo el caso del Camarín de Tepotzotlán, de 1679- y ninguno habría sido construido en una fecha tan tardía como el de Aguascalientes. Esto plantea una serie de interrogantes respecto a la atribución estilística: considérese que en nuestro caso el monumento se levanta en pleno período de vigencia y empuje del Neoclásico, como resultado de las Reformas Borbónicas implementadas por la Corona en Nueva España. Aunque podríamos suponer que el Camarín de San Diego pudo haber sido el último del período novohispano, quizá debiéramos hacernos eco, en este sentido, de la recomendación de Clara Bargellini respecto a privarnos de la tentación de adjetivar un edificio determinado hasta no tener amplios

29. Secretaría de Asentamientos Humanos y Obras Públicas, Vocabulario arquitectónico ilustrado, México, 1980, p. 88. 
estudios de la serie a la que pertenece; y ese parece ser el caso del Camarín de la Inmaculada de Aguascalientes.

\author{
El PATRONAZGO BARROCO EN LA ERA REGALISTA \\ Y EL EFECTO DE LAS REFORMAS BORBÓNICAS EN EL CAMPO \\ DE LA EDIFICACIÓN: EL CAMARÍN, UN CASO SUI GENERIS
}

El Camarín de San Diego es un edificio extraordinariamente atípico y único por varias razones: por las fechas de su construcción, por su distribución en una planta circular y una cúpula esférica sobre tambor también circular y no una cúpula agallonada; por la coexistencia, en su diseño, de patrones geométricos clasicistas y resabios de la arquitectura del estípite, y particularmente del estípite y del barroco que estuvo de moda en Aguascalientes en el último tercio del XVIII, manifiesto en el uso de cortinajes y guardamalletas de cuño guanajuatense; por la presencia de rasgos tímidos del neóstilo, "la última carta del barroco novohispano"; por su concepción ambivalente, producto de la conciliación entre el patronazgo pietista de su donadòr material, y el contenido académico y por ende regalista de su concepción espacial y formal; por la intervención en su fábrica de un maestro alarife que desplegó con desenfado las diferentes tradiciones de su aprendizaje: la formación de la escuela de Felipe de Ureña y la de la moda promovida por Tresguerras en la región; por la aparentemente opuesta presencia de dos diferentes formas de organización del trabajo: una plenamente artesanal de cuño gremial, y otra propia de las nuevas condiciones impuestas por las Reformas Borbónicas, manifiesta en el uso de nuevos materiales, técnicas de construcción y formas clásicas "racionales" que se impulsaron a través de la Academia; por la utilización evidente de mano de obra regional y la presencia de varios maestros canteros en la escultura arquitectónica, colocados frente al reto de labrar la piedra con un diseño de líneas muy clásicas y armonizarlo con elementos barrocos. En suma, el hecho esencial para la historia del 
arte y de la arquitectura es la aparente contraposición, en el Camarín, entre la concepción patrimonialista y la solución formal regalista que lo caracteriza. Oposición aparente porque es un hecho que en el monumento sus términos se encuentran conciliados y que su constructor, Santiago Medina, los amalgamó antes que acusar su sentido contrapuesto. ¿Cómo fue posible un edificio de esta naturaleza en circunstancias ideológicas tan adversas? Pueden aducirse razones históricas irrecusables, que se exponen de modo muy sucinto en este apartado.

Con el proceso de reformulación de las relaciones entre la Casa de los Borbones y sus dominios en América dieron inicio importantes cambios a todos los niveles de la vida y el mundo novohispano. Así, en este último sentido, a la escolástica tradicional se opuso la racionalidad y el empirismo del nuevo y moderno proyecto ilustrado. La religiosidad dieciochesca, basada en el valor inmanentista de las obras pías, nuevamente sufrió un vuelco hacia el predominio de conceptos cívicos que canalizaban el prestigio social por rutas no religiosas. En los campos del arte, los oficios y la arquitectura, sintiéronse con vigor los cambios introducidos y en este contexto surge la necesidad histórica de la Academia de San Carlos, creada para la formación de artistas y artesanos liberados de las ataduras gremiales y sus métodos de aprendizaje y de trabajo, redefiniendo la condición del artista y su medio en términos de estatus ${ }^{30}$ separando el trabajo manual del trabajo intelectual y, por ende, privilegiando al artista sobre el artesano. Ello suponía dejar libre al primero para incrementar su producción e insertarla en el mercado local, lo que equivalía, ni más ni menos, a "promover la producción artística y artesanal como mercancía para un mercado de tendencias capitalis-

30. Todo este parágrafo, basado en Fausto Ramírez, "El Arte del siglo XIX", en Historia del Arte Mexicano, Arte del siglo XIX I, Tomo 9, SEP-Salvat, México, 1982, p. 1219. Ver también Sonia Lombardo, "Las Reformas Borbónicas y su influencia en el Arte de la Nueva España”, en el mismo tomo, p. 1236. 


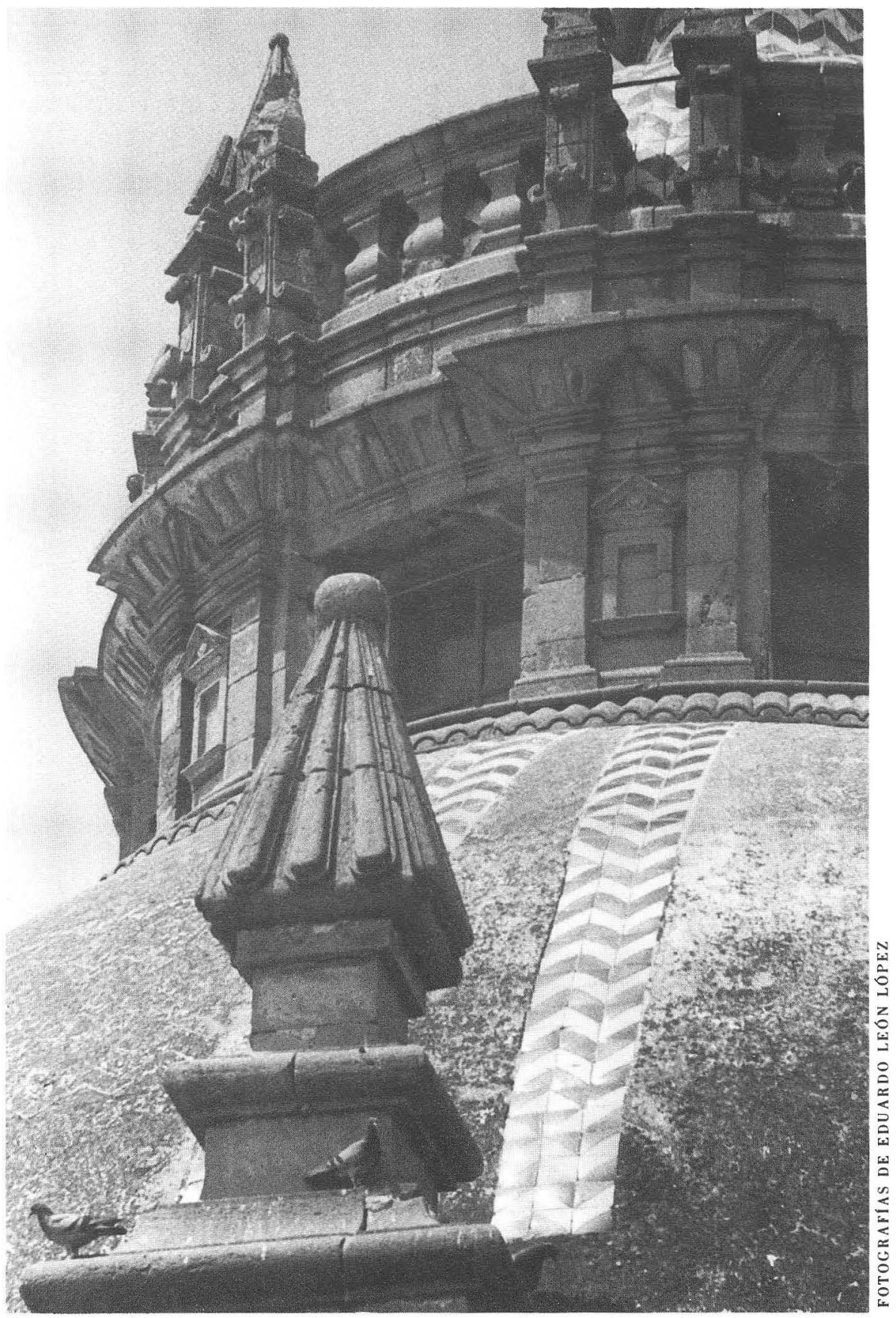

C A 


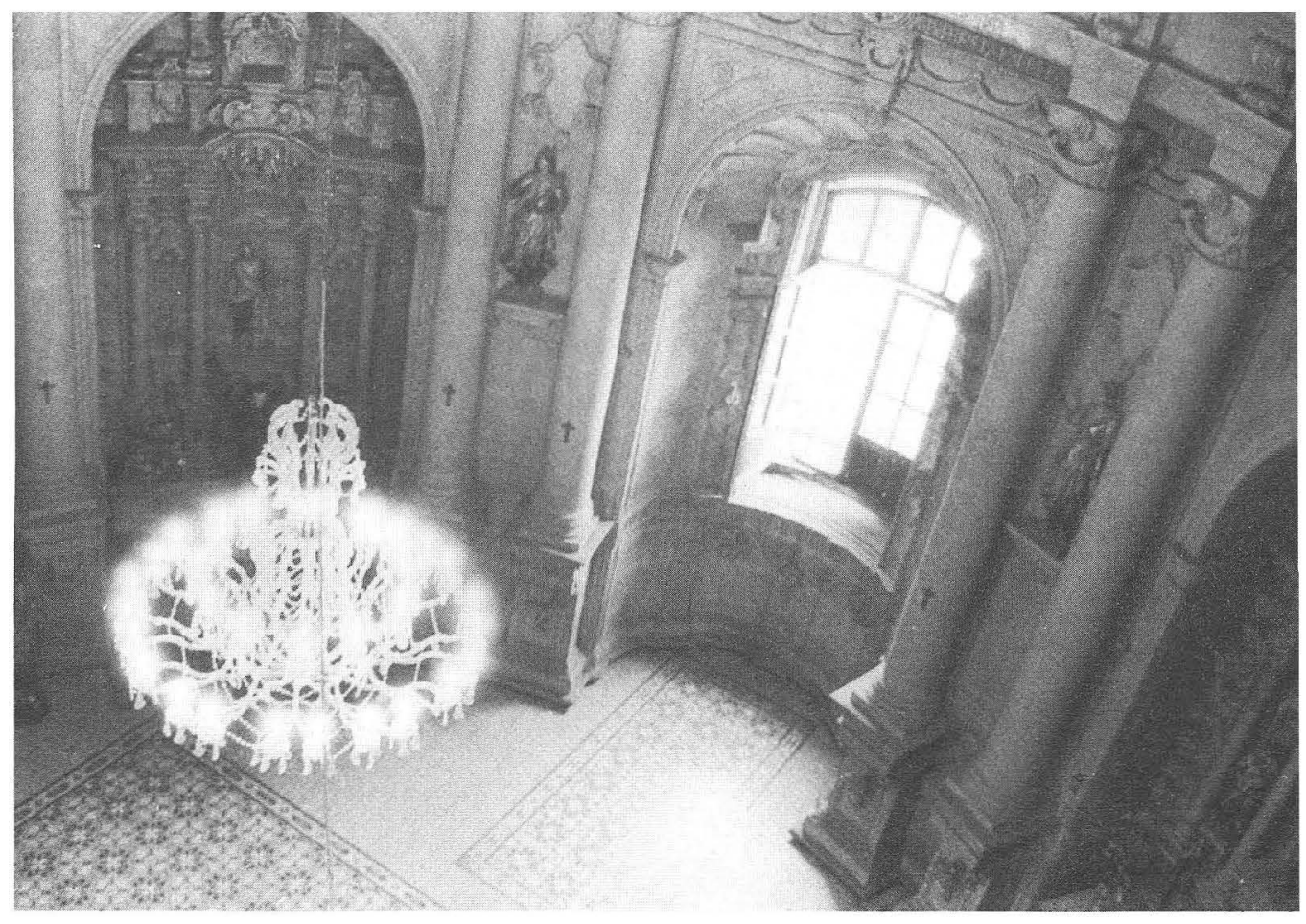

C C A A 


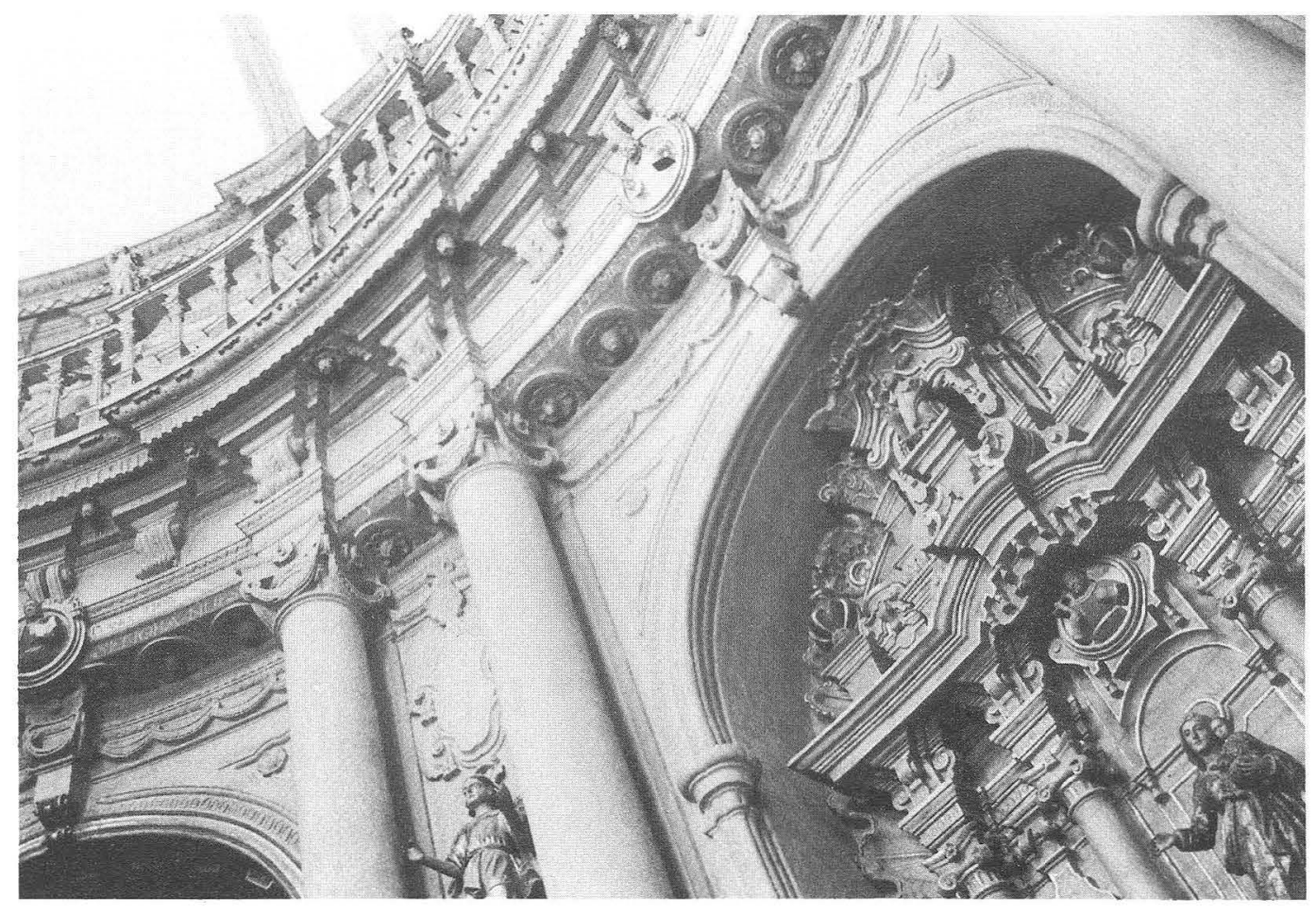




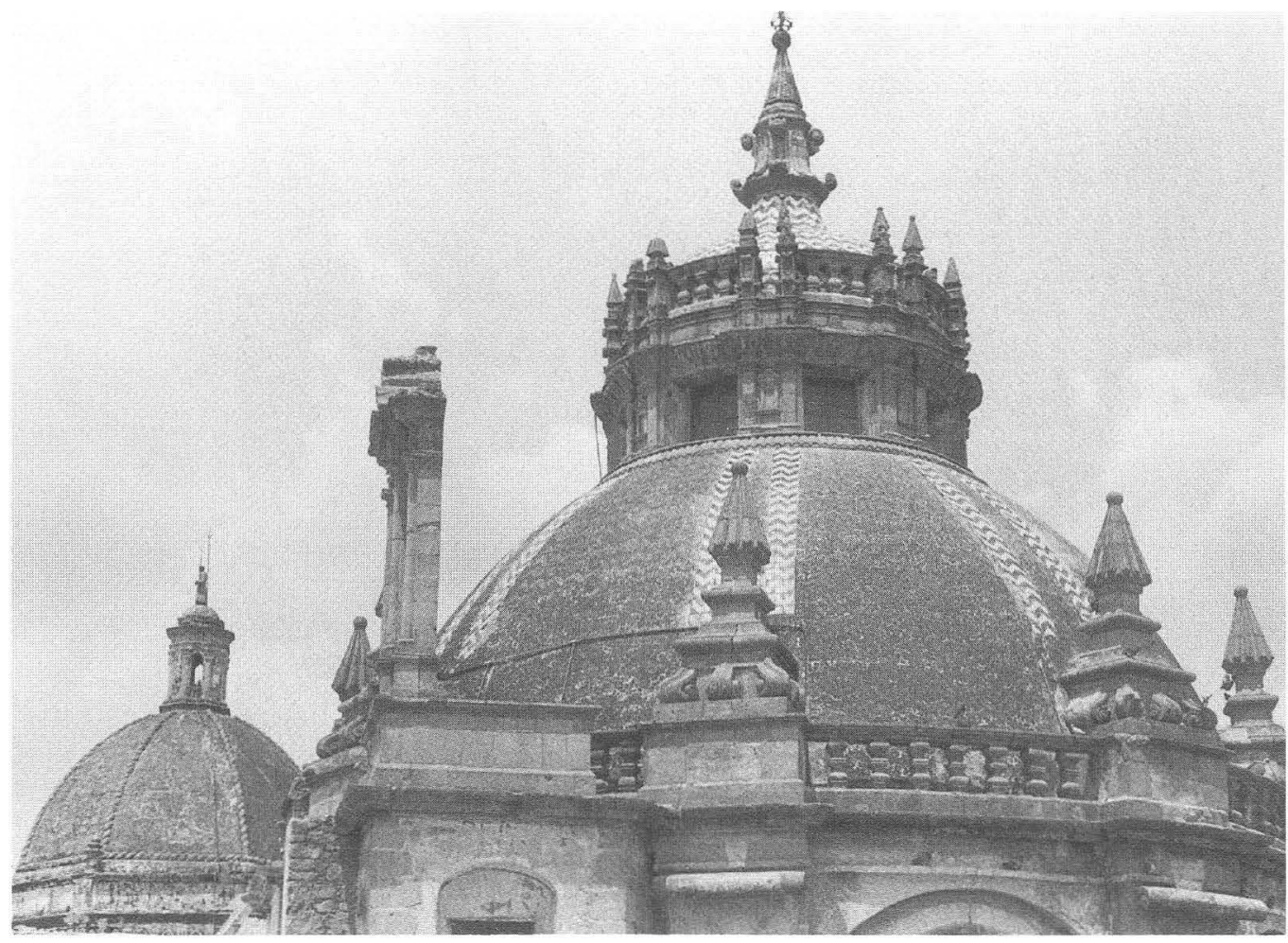

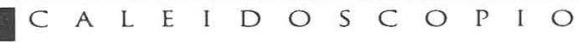


tas, basado en la libre competencia...." ${ }^{31}$ Los gremios, en su calidad de instituciones corporativas y cerradas de regulación productiva, señala Fausto Ramírez, eran un obstáculo al proyecto modernizador borbónico. ${ }^{32}$

En este contexto, la necesidad de nuevos tipos de espacios y programas arquitectónicos demandó el desarrollo e impulso de novedosos materiales de construcción y de nuevos métodos de trabajo y de organización del mismo. El mármol blanco se convirtió en el material de moda del gusto neoclásico (tal como se aprecia en el ciprés de alabastro del Camarín), se abandonó la policromía por una cromática marmórea; Manuel Tolsá incluso promovió el uso del yeso como material sustituto de la madera en los retablos (nuevamente, el Camarín ilustra el punto)..$^{33}$

Todas estas circunstancias determinaron el desplazamiento de la Iglesia como patrocinadora y consumidora de arte, siendo sustituida por las veleidades áulicas de los Borbones. La iconografía privilegió entonces temáticas paganas, con recio sabor clasicista, en sustitución de las temáticas religiosas tradicionales, ${ }^{34} \mathrm{La}$ arquitectura, de este modo, adquirió un tinte más laico que religioso. Pareciera, pues, que todo el cuadro de las nuevas condiciones jugaba en contra de la pervivencia del ancien régime y de sus manifestaciones en el arte y la arquitectura. Sin embargo, y éste es el punto fundamental, estas condiciones rigieron de hecho y de derecho particularmente más para la metrópoli novohispana que para la provincia, en donde su vigencia fue más bien ideal. De hecho, la revolución administrativa de los Borbones generó fuertes resistencias en el sistema de privilegios e intereses detentados por las diversas corporaciones -la vieja burocracia virreinal, la Iglesia y los gre-

31. Sonia Lombardo, Ibid., p. 1241.

32. Fausto Ramírez, Op. cit., p. 1220.

33. Sonia Lombardo, Op.cit., pp. 1250, 1252 y 1260.

34. Ibid., p. 1249. 
mios-; aun los mismos criollos ilustrados no aceptaron de inicio la nueva situación por considerarla una imposición central..$^{35}$ Los virreyes, por su parte, retardaron la aplicación de las reformas porque comprendieron que sus intereses eran afectados.

Ahora bien, la reticencia osciló entre formas radicales de oposición y formas híbridas. En el terreno de la arquitectura, por ejemplo, la Academia de San Carlos no dejó de extender su influencia a las corporaciones de varias maneras: gremios y artesanos adoptaron en ciertos casos algunos aspectos de la nueva "morfología" y de sus presupuestos espaciales, tales como la unidad de tiempo y espacio dada por la perspectiva geométrica. ${ }^{36} \mathrm{La}$ sencillez, la claridad y la fuerza de líneas (racionalismo) y el naturalismo (empirismo) poco a poco comenzaron a ganar terreno no sólo entre los académicos, sino también entre los maestros. Los estatutos de la Academia, además, sólo entraron en vigor al principio en la ciudad de México, no en la provincia, en donde el sistema gremial operó hasta su disolución en 1813 (de hecho, hasta 1808 se consideró la conveniencia de ampliar la acción de la Academia hacia el interior). Los artesanos, por otro lado, contravinieron con frecuencia las Ordenanzas de sus gremios cuando se encontraron en dificultades financieras para la apertura de sus talleres, siendo refaccionados por los comerciantes, quienes podían actuar con libertad por estar al margen de las corporaciones.

En la provincia, el lenguaje contradictorio del sistema borbónico, impuesto desde su matriz metropolitana virreinal (es decir, aquél que expresa "formas de apariencia moderna arraigadas en concepciones profundamente tradicionales"), se acentuó por la pervivencia de las formas religiosas y el poder de las corporaciones. Estas pruebas de la inoperancia y/o atemperancia de las reformas en un medio como el de la provincia explican porqué pudo ser posible

35. F. Ramírez, Op. cit., p. 1221.

36. Ibid. 
una obra de concepción patrimonialista y solución regalista en Aguascalientes, y porqué un maestro como Santiago Medina pudo conciliar las tradiciones contrapuestas de su formación: las condiciones históricas lo permitieron. ${ }^{37}$

Si los códigos académicos vigentes en la ciudad de México seguían conservando rasgos barrocos por su solución espacial y plástica, aunque fueran neoclásicos por su programa específico (como en el caso del Palacio de Minería), ${ }^{38}$ en la provincia, por el contrario, buen número de monumentos seguían siendo barrocos por la concepción de su programa específico, mientras eran neoclásicos -0 cuasineoclásicos, o neóstilos-por su solución espacial y plástica. Y éste fue precisamente el caso del Camarín de la Inmaculada de Aguascalientes.

\section{LA DEVOCIÓN INMACULISTA EN LA REGIÓN:}

JuAN Francisco CaLERA Y LAS EXCELSITUDES DE SU CAUDAL

Ante este panorama, no era de extrañar que la religiosidad pietista siguiera resonando entre acaudalados individuos al interior cel territorio novohispano. De hecho, las devociones religiosas activaron no sólo las conciencias, sino que permitieron el desarrollo de la edificación gracias a las donaciones y capellanías que se fincaban sobre los edificios. En la región, por razones históricas que no nos atañe reseñar, desde el siglo XVI dos fueron las devociones más favorecidas y en honor de las cuales fueron fundadas villas españolas y levantado templos monumentales: la de la Inmaculada Concepción y la de la Asunción. Tanto la villa de Aguascalientes como la de Santa María de los Lagos erigieron sus respectivas parroquias a la advocación mariana de la Asunción, mientras que la villa de San Juan de los Lagos lo hacía a la advocación de la Inmaculada, que

37. Sonia Lombardo, Op. cit., pp. 1244-1265.

38. Ibid., p. 1257. 
no sólo fue venerada por el clero diocesano, sino muy señaladamente por el clero regular y particularmente por los franciscanos.

Aquella religiosidad pietista de la que hablábamos líneas arriba caló hondo, pues, entre los espíritus de los piadosos hombres de la pequeña villa de Aguascalientes. Así lo atestiguan los diversos recintos para las devociones dieciochescas que desde entonces engalanaron la ciudad: la parroquia dedicada a la Virgen de la Asunción, el templo de San Marcos, el santuario de Guadalupe, el templo de San José, el del Señor del Encino, el del Rosario y el de San Juan Nepomuceno, todos del siglo XVIII. Y desde luego, el grupo integrado por el templo y convento de San Diego y la iglesia de Tercera Orden. Gracias a la especial devoción de Don Juan Francisco Calera por la Purísima Concepción, fue posible la erección del Camarín de la Virgen, sin duda uno de los más hermosos monumentos dieciochescos por la belleza de sus formas y sus proporciones, y por su inusual disposición en planta, que lo hace único no sólo en la región sino en todo el país.

¿Quién era Juan Francisco Calera? ¿Qué circunstancias lo llevaron a donar una obra tan onerosa? ¿De dónde provino su fortuna? Son todavía insuficientes los datos sobre este personaje, pero son lo bastante justos como para reconstruir su circunstancia personal e insertarla dentro de procesos más generales de la sociedad novohispana del siglo XVIII, fundamentalmente dos: el fenómeno del patronazgo de obras pías, y el de la formación de una burguesía comercial de origen peninsular en la Nueva España. En efecto, Juan Francisco Calera no sólo era síndico del convento de San Diego y patrón material del Camarín de la Virgen, sino comerciante peninsular y más tarde capitán y teniente coronel de las milicias de Dragones de la Nueva Galicia. Con toda probabilidad fue un personaje de algún caudal en la villa de Aguascalientes. ¿Cómo fue su proceso? Recurramos a D. Brading:

Los siglos XVII y XVIII son los siglos del encumbramiento de un nuevo tipo de ser social: el "burgués novohispano". Brading sos- 
tiene que había una "mal definida" clase alta formada "enteramente" por españoles, reconocida por su riqueza, por su ocupación, privilegios de sangre, educación y costumbres españolas. Para este autor, conformaban una élite un tanto inestable como grupo, al grado que, en palabras de Lucas Alamán -citado por el autor-cuando la riqueza fenecía, el individuo "volvía a caer en la clase común..." La mayoría de los españoles peninsulares residentes en la Colonia pertenecían a esta élite, y de entre éstos, los más numerosos eran los comerciantes, que llegaron a gozar de un prestigio social igual al de los hacendados. Sus actitudes, decía el Virrey Mancera (citado por Brading), “...se acercan mucho a la nobleza, afectando su porte y tratamiento (...) puede suponerse que en estas provincias por la mayor parte el caballero es mercader y el mercader es caballero".

Muchos de ellos comenzaron a trabajar como aprendices de comerciantes o como cajeros (denominación común por aquellos días), y la mayoría eran inmigrantes que venían de las montañas del norte de España, de lugares como la Cantabria, de Navarra, Asturias, montañas de Burgos y Galicia. Lo curioso es que eran campesinos empobrecidos que probaron fortuna primero en Castilla y más tarde allende los mares, y que ostentaban una característica peculiar: su lealtad al terruño, acentuada por su propensión a mostrar una particular devoción religiosa o caritativa. Ambos grupos, dice Brading, tenían pretensiones nobiliarias y pasión genealógica, y parece ser que en el norte de España, y en Guipúzcoa particularmente, "todo el mundo era hidalgo". Pero en la Nueva España la incertidumbre del origen desaparecía, ya que aquí los españoles eran considerados hidalgos por regla general y además, como conquistadores, reclamaban una posición superior.

Una vez instalados en la Nueva España, estos hijosdalgo comenzaban como aprendices o cajeros en los establecimientos de parientes, frecuentemente sus tíos o algún paisano de su mismo valle 0 provincia, y vivían bajo un sistema "casi monástico", lo que iba muy a tono con sus profundas convicciones, ya que "viéndose en 
un medio irresponsable en el que abundan los borrachos y la pereza, los inmigrantes fortalecían la conciencia de su superioridad mediante su profunda devoción religiosa y con la consolidación de sus fortunas". Dos factores clave originaron el éxito de estos individuos: el comercio y el matrimonio; así, al cabo de su aprendizaje, su patrón-que era su pariente- los convertía en socios o establecían su propio negocio con capital de aquél o con mercancías a crédito, otorgadas por el propio pariente; asimismo, tenían "preferencias" en el "mercado del matrimonio", ya que los patrones casaban a sus hijas con los sobrinos venidos de España para así continuar con el negocio, o las viudas de aquéllos se casaban con estos últimos para el mismo fin. Esto daba a esta élite un carácter mercantil y empresarial semihereditario y prácticamente endógamo. ${ }^{39}$

Juan Francisco Calera era hijo de Don Juan Calera y de Doña Lucía de Obregón y Arce. Al momento presente aún no hemos podido encontrar documento alguno del origen preciso de esta familia, pero es muy probable que efectivamente tuviera sus antecedentes en una familia norteña, dado que uno de los primos de Don Juan Francisco, llamado Tirso Antonio Calera, era natural y vecino del lugar de Sano, en el Valle de Carriedo, montañas de Burgos, Obispado de Santander, en el Reino de Castilla La Vieja. ${ }^{40}$ La primera noticia directa de que disponemos en relación a este personaje lo ubica en el año de 1780 como "vecino y del comercio" de la villa de Aguascalientes. ${ }^{41}$ Lo anterior nos conduce a pensar que ya para entonces nuestro personaje estaba perfectamente establecido en la ciu-

39. Estos parágrafos, condensados de David A. Brading, Mineros y Comerciantes en el México Borbónico (1763-1810), Fondo de Cultura Económica, México, 1985, pp. 39-284. Ver también Vicente Ribes Iborra, El Norte de la Nueva España en 1770. Vida y Obra de Mateo de Arteaga, Universidad Autónoma de Aguascalientes, 1990, p. 17. Los abuelos de don Mateo Joseph de Arteaga, dice este autor, provenían "de una de esas familias hidalgas, pero pobres, que tanto abundaban en las tierras del Norte de la península ibérica".

40. Estas informaciones en AHEA, FPN, Caja 34, Exp. 6, Escritura 7, F. 14f- $15 f$.

41. AHEA, FPN, Caja 83, Exp. 2, Escritura 44, F. 54v-55v. 
dad y que con toda seguridad se trataba de un individuo de alguna importancia, a juzgar por el contenido del poder especial otorgado en aquélla y otras escrituras existentes en el Archivo Histórico. ${ }^{42}$

Juan Francisco era hermano de Pedro Manuel Calera, ${ }^{43}$ importante comerciante y en algún momento administrador de alcabalas de la villa hacia 1768, de quien tenemos noticia directa en el Archivo Histórico desde el año de 1764. ${ }^{44}$ La información que proporciona el Fondo de Protocolos Notariales para estos dos personajes no nos deja lugar a dudas de su relativa importancia dentro del comercio de la villa y del valor de sus respectivos caudales, que con toda seguridad fueron en crecimiento, a juzgar por las múltiples operaciones de compra-venta de inmuebles y otros rubros. No estamos en condiciones de afirmar todavía si los hermanos Calera fueron de aquellos comerciantes venidos a la Nueva España a probar fortuna, pero en todo caso podemos tener por cierto su origen peninsular, dado que en la escritura de poder que otorgó a su primo Tirso Antonio Calera, Juan Francisco le solicita a éste "pida, y haga sus Informaciones de Hidalguía, y Nobleza" ${ }^{45}$ Cómo y cuándo llegaron a la Colonia y a la villa de Aguascalientes es cosa que todavía desconocemos. Tenemos que partir del hecho de su establecimiento en la ciudad y de que sus negocios les habrían reportado suficientes ganancias como para alcanzar una fortuna de alguna importancia, aunque todavía no tenemos elementos para saber si la de Juan Francisco podía ubicarse entre las 12 más dilatadas que por el año de 1789 consignaba José Menéndez Valdés para el caso de Aguascalientes. ${ }^{46}$ Con seguridad, el caudal y las profundas de-

42. AHEA, FPN, Caja 83, Exp. 2, Escritura 54, F. 71v-72v.

43. La prueba documental del parentesco en AHEA, FPN, Caja 26, Exp. 3, Escritura 5, F. 7f-8f.

44. AHEA, FPN, Caja 22, Exp. 3, Escritura 45, F. 7lf-73v. También AHEA, FPn, Caja 22, Exp.7, Escritura 28, F. 55v-57v.

45. AHEA, FPN, Caja 34, Exp. 6, Escritura 7, F. 14f-15f.

46. José Menéndez Valdés, Descripción y Censo General de la Intendencia de Guadalajara, 1789-1793, Guadalajara, 1980, p. 51. 
vociones de nuestro personaje tuvieron que ver en su nombramiento como Síndico del Convento de San Diego.

De la devoción tan profunda de Juan Francisco por la Inmaculada nos da cuenta su donación para la construcción del "suntuoso" Camarín, en la parte posterior del presbiterio del templo de San Diego. Sobre la autoría del patrocinio material no puede existir ya duda alguna: la obra fue debida a la generosidad del personaje, como lo prueba la siguiente cita:

Que por la grande Devocion, y crecido afecto que ha tenido siempre a Maria SSma en su Inmaculada Consepcion le ha construido a expensas de su caudal a esta Soberana Reyna un magnifico Camarín en el Combento de Religiosos Descalzos de San Diego en esta Villa... ${ }^{47}$

$\mathrm{Al}$ respecto, Ochoa recoge una información de documentos del archivo conventual de San Diego de Aguascalientes, de fecha 5 de julio de 1799, y de la sala Capitular de San Diego de México, de mayo 24 del mismo año, que recogemos ampliamente:

Por cuanto la grande y devota generosidad de Vmd. ha construido dentro de los muros del mismo Convento un magnífico Camarín desde sus cimientos, no tan sólamente de su propio peculio, sino también de su personal asistencia, dirección y cuidado y ha verificado su completo adorno para todo lo cual ha erogado más de treinta mil pesos sin permitir se colectase ni un medio real de limosna y para satisfacer Vmd. los abrasados deseos de su fervorosa devoción ha fabricado de rico y vistoso alabastro el ciprés de su Nicho, de sus frentes en la una existe el tabernáculo del Santísimo Señor Sacramentado de la Iglesia del referido Convento en beneficio de cuyo lustre honor y utilidad Vmd. se ha servido manifestarse siempre sumamente apasionado; Por tanto, concediendo con la piadosa solicitud de Ud. le declaramos y nombramos en quanto se extienden todas nuestras facultades y de derecho podemos, por Patrono único y legítimo y a sus desendientes del citado Camarín y que como tal patrono pueda poner en él su Estatua, el Escudo de sus armas y silla para su asiento. Así mismo que la Sagrada Imagen de la Purísima Concepción, se haya de voltear acia el Camarín (proporcionando la comodidad

47. AHEA, FPN, Caja 34, Exp. 3, Escritura 8. F. 18f-2lf. 
para ello) al tiempo de celebrarse Misa que la devoción de Vmd. ha dotado para todos los Sábados y para las Cuatro festividades principales de la Soberana Reyna con tal que no este expuesto el Divinísimo Señor Sacramentado o se haya de selebrar Missa conventual, sin que pueda estorbarlo Religioso alguno Subdito prelado inferior a Nos. ${ }^{+8}$

Otras prerrogativas fueron concedidas a Calera: sepultura a él y su esposa "si Vmd. tubiere a bien contraer matrimonio", y misa de Réquiem para después de sus días. Y en fin, en uno de los cintillos por debajo de la majestuosa cúpula del recinto, en el entablamento cilíndrico soportado por las columnas, se lee:

"EL DIA 2 DE SEPTIEMBRE DEL AÑO DE 1792 SE DIO PRINCIPIO A LA FABRICA DE ESTE CAMARIN QUE SE CONSTRUIO A ESPENSAS DEL CAUDAL DEL CAP. DON JUN FRANCISo. CALERA SINDICO DE ESTE COMBENTO QUIEN LO DEDICO A LA PURISIMA YMMACULADA CONCEPCION DE MARIA SANTISIMA SEÑORA NUESTRA Y SE CONCLUIO EL MES DE ABRIL DE 1797".

Inscripción que revela sin género de duda la personalidad del donador y benefactor material, así como el patronazgo del monumento, propio de la piedad barroca.

El Camarín. Fuentes estilísticas, FÁBRICA Y ETAPAS CONSTRUCTIVAS

El diseño general del edificio se ciñe a los modelos de la arquitectura clásica y su solución a las normas de composición regidas por trazos armónicos, a juzgar por la belleza de sus proporciones y la claridad con que los diversos elementos arquitectónicos se disponen en el espacio. De hecho, la planta del edificio sigue el mismo patrón proporcional y el mismo perfil interior del Panteón de Ro-

48. Ochoa, Op. cit., pp. 31-32. 
ma, salvo por las adecuaciones necesarias por la función distinta que el Camarín desempeñaba, y por sus diferentes dimensiones. Esto no era de extrañar entre los artesanos y artistas de los siglos XVI, XVII y XVIII, quienes, ante la imposibilidad de conocer sus modelos en el sitio de su ubicación, recurrían a los grabados que llegaban de Europa en las ediciones que circulaban con alguna profusión por aquel entonces. Ello no demeritaba en modo alguno el trabajo de los artífices locales; por el contrario, lo realzaba, dado que aquí se infundían en el diseño las propias aspiraciones, anhelos e inventiva de sus creadores. Y ahí queda el barroco estípite como primer ejemplo. Desde luego no era improbable, como lo argumentaremos en otro apartado, que Santiago Medina conociera los tratados de Serlio y que en ellos haya visto plasmados los planos del Panteón Romano, inspirándose en los mismos para la construcción del Camarín. Por lo demás, la época era muy propicia en cuanto al rescate de las tradiciones clásicas, incluso entre los mismos maestros alarifes.

Sin embargo, hemos constatado que en el Camarín coexisten armónicamente elementos barrocos junto a los patrones geométricos de la arquitectura académica, que señalamos obedecen a la ambivalencia de la formación de Santiago Medina, a la imposición de Juan Francisco Calera, dadas sus devociones pietistas y plenamente barrocas, o ambas cosas. El diseño clásico, reiteramos, se explica por la entronización de la ideología regalista y racional promovida por las Reformas Borbónicas, mientras que el ornato barroco presente en algunos elementos nos habla del concepto patrimonialista ligado a la Iglesia. Así, los accesos al Camarín presentan portadas de pleno movimiento, y no sólo por el perfil circular del edificio, sino por su propio impulso, retorciéndose voluptuosa la cantera, denotando un excelente trabajo en su labrado. Dichas portadas presentan rasgos asociados al barroco estípite, como por ejemplo las guardemalletas de los apoyos, los roleos a la manera de rocallas, las pilastras estípites en las que se acusa el círculo apendicular muy propio de la arquitectura de Felipe de Ureña; en fin, un trabajo refinado 
que sin embargo contrasta con el de otros elementos del interior del Camarín, en donde la piedra acusa cierto labrado tosco pero efectista, que denota con alguna seguridad la presencia de varios canteros bajo la dirección de Santiago Medina. Nos referimos particularmente a las ménsulas que soportan las basas de las columnas. En dichas columnas, incluso, se observan diferentes trabajos -probablemente a destajo-, evidenciados por las distintas dimensiones de las piezas que conforman los fustes. Lo mismo podría decirse de las guirnaldas que adornan los capiteles y el entablamento, cuya talla presenta desigualdades difícilmente aceptables para la racionalidad técnica de los académicos. Lo anterior no demerita en modo alguno el excelente resultado de conjunto del monumento, cuyo secreto estriba en la belleza de sus proporciones.

Llama la atención un par de estípites que enmarcan la ventana que mira hacia el norte. Son de claro diseño "ureñano", lo cual se evidencia nuevamente por la presencia del círculo apendicular y cierto carácter "delineado", dibujístico -en todo caso antinaturalista- de su perfil. Sobre las puertas de ingreso, por el interior del Camarín, se observan sendas veneras casi en forma de nicho que delatan su procedencia barroca. El resto de la decoración es de clara filiación neoclásica o bien con rasgos acentuados provenientes de la arquitectura de Lagos de Moreno, salvo por los retablos barrocos que alojan a la parentela cercana a la Virgen, cuyo diseño recuerda ciertos parámetros pertenecientes al neóstilo, al descubrirse dos rasgos esenciales de esta modalidad: el fuste liso de las columnillas que enmarcan los cuerpos de diseño clasicista, y los elementos entre ellas, que remiten a ciertas soluciones interestípite que a su vez sugieren la persistencia de los códigos de la arquitectura "posbalbasiana", fundamental en la atribución de las obras neóstilas.

Asimismo, la linternilla es de diseño netamente neoclásico (foto No. 1), ornada con pináculos perimetrales y una balaustrada bien proporcionada, aun cuando el remate superior acuse cierto barroquismo en las "costillas", terminadas con roleos en sus extremos. 
El contorno mismo del cupulín de la linternilla sugiere una solución igualmente barroca, ya que se delinea a partir del arco llamado conopial. La majestuosa cúpula, en cambio, evidencia un perfil y diseño enteramente racional por cuanto parece obedecer a un trazo geométrico perfectamente definido y a cálculos precisos.

Con todo, nos guardamos de considerar al monumento como neóstilo sin más. Según María Cristina Montoya, el neóstilo, como "último intento de supervivencia del barroco", orienta su espíritu hacia "directrices más dinámicas", aunque -y he aquí el punto-, dentro de los límites de la órbita barroca, ${ }^{49}$ particularmente de la arquitectura "posbalbasiana" o "posureñana". Manrique sostiene que su apogeo se da en dos momentos: entre 1770-75 y 1790-95. ${ }^{50}$ Las portadas neóstilas se carecterizan por presentar "...columnas o a veces, pilastras clásicas de fuste liso o estriado", sin embargo, son barrocas porque "casi nunca cumplen totalmente su función sustentante y cuando lo hacen no van seguidas de todos los elementos de un entablamento". ${ }^{51}$ Según la misma autora, las "contadas excepciones" de plantas y estructuras no inmóviles se dieron en la etapa que ella denomina "ultrabarroca", siendo por el neóstilo que se introdujo una importante novedad: "al mover las plantas y alzados, se crearon diferentes ambientes arquitectónicos donde se consiguieron efectos de iluminación y movimiento nunca antes vistos". ${ }^{52}$ El Camarín de San Diego podría ser uno de esos edificios, aunque, insistimos, no nos resolvemos totalmente por considerarlo neóstilo, dadas sus extraordinarias peculiaridades.

El Camarín presenta en el interior dos accesos en el sentido oriente-poniente y otros dos huecos en el norte-sur; el meridional

49. María Cristina Montoya R., "Variantes de la Arquitectura barroca religiosa en la metrópoli y en los estados de México, Hidalgo y Guerrero", en Historia del Arte Mexicano, Arte Colonial II, Tomo 6, p. 850.

50. Jorge Alberto Manrique, citado por Montoya, Ibid.

51. Ibid.

52. Ibid., p. 851. 
aloja un ciprés neoclásico que enmarca la imagen de la Purísima Concepción, patrona del Convento, Iglesia y Camarín. Cuatro nichos en ángulo de 45 grados respecto a los huecos anteriores alojan otros tantos altares que corresponden, respectivamente (contando a partir del acceso desde el actual convento y en sentido de las manecillas del reloj), a los retablos barrocos de San Juan Bautista, San José, San Joaquín y Santa Ana. Los elementos decorativos y el diseño general definen una clara delimitación de la escultura arquitectónica respecto de sus soportes tectónicos, confiriendo al espacio una riqueza monumental sustentada por las líneas clásicas de su geometría y por la coexistencia armónica de resabios barrocos, tales como algunos estípites, guardamalletas y cortinajes del último período barroco, de gran abolengo en Aguascalientes. Levantadas sobre basas, que a su vez arrancan de ménsulas que acusan graciosos roleos y acanaladuras, dieciséis columnas dispuestas en pares, lisas y exentas, terminan en capiteles jónicos ornados con guirnaldas, que soportan un entablamento, cuya cornisa de remate vuela generosamente para permitir un deambulatorio superior al pie del arranque de la cúpula. Katzman, sobre esta última solución en los capiteles, afirma que

El jónico de ocho volutas lo encontramos primeramente en el camarín de la iglesia de San Diego en Aguascalientes (...); allí mismo el jónico con guirnaldas llamado a veces jónico compuesto, que fue una variante barroca nunca admitida por los tratadistas del Renacimiento. El capitel de ocho volutas con guirnaldas fue el preferido por Tolsá, González Velázquez y Tresguerras...

El modelo de este capitel, según Katzman, proviene de Scamozzi (siglo XVIII). Varios aspectos de este autor pueden ser rescatados para apoyar los planteamientos de nuestro estudio: en primer lugar, constata que la arquitectura clasicista es posterior a 1790, y en ella

53. Ver Israel Katzman, Op. cit., p. 79. 
la columna predominante fue la jónica, en un período que va de este último año hasta el de 1810, si bien se utilizaron los tres órdenes y sus variantes: toscano-dórico, compuesto-corintio. Hasta el siglo xVIII los órdenes en la Nueva España fueron planos, embarrados y bidimensionales, mientras que a fines esta centuria, es decir, en tiempos de la construcción del Camarín, el clasicismo adquiere mayor espontaneidad y tridimensionalidad, siendo entonces comunes las columnas exentas y presentadas en pares (foto No. 2). El arco sobre dos tramos de entablamento que se apoyan en columnas fue una variante del Renacimiento italiano y que "Se encuentra un poco disimulado en los retablos del camarín de San Diego en Aguascalientes". ${ }^{54}$ Todo lo anterior refuerza la hipótesis de la influencia que estas tendencias pudieron ejercer en Santiago Medina (y particularmente la de Tresguerras), sin.menoscabo alguno de su formación en la escuela barroca de Felipe de Ureña.

En bustos realzados en forma de medallón aparecen, en el primer cuerpo del edificio, las imágenes de San Mateo Evangelista, San Ambrosio, San Marcos Evangelista, San Agustín, San Lucas Evangelista, San Gregorio Magno, San Juan Evangelista y San Jerónimo. En el segundo cuerpo, que corresponde al arranque de la cúpula, aparecen otros medallones con las imágenes de San Juan Damasceno, Sutil Escoto, San Gregorio Nacianceno, V. Padre Ceres, San Alberto Magno, Santa Teresa, V. Padre Cornelio y la V. Madre Agreda. Entre las columnas se observan ángeles y sobre la balaustrada aparecen angelillos "mongíbelos" o "ceriferarios", en número de dieciséis (aunque uno de ellos actualmente está perdido o fuera de su lugar).

El exterior presenta sólidos y robustos contrafuertes para contrarrestar el empuje de la grandiosa cúpula; en su cuerpo bajo sobresalen generosas claraboyas para permitir la iluminación a ese nivel, mientras que la linternilla presenta vanos de trazo muy clásico por

54. Ibid., pp. 79-100. 
los que se filtra la luz al interior de la cúpula. Bajo el nivel del Camarín se localiza la cripta o "catacumbas" que han dado fama al edificio y, a su vez, bajo el nivel de la cripta, por informaciones de los frailes sabemos que existe un antiguo cementerio, actualmente cegado.

Se han logrado identificar tres etapas constructivas en el desarrollo de la edificación del Camarín. La primera corresponde a la construcción de las galerías subterráneas del cementerio y la cripta, obra que habría sido terminada hacia $1768-69$, según informaciones de Topete del Valle, ${ }^{55}$ lo que apuntala nuestra hipótesis general de la procedencia barroca original del recinto. En la cripta se hicieron modificaciones -fundamentalmente en la decoración- en agosto de 1954, según consta en una inscripción que se localiza encima del arco apuntado del acceso desde el actual convento.

La segunda etapa constructiva corresponde a la edificación de la estructura portante de muros y contrafuertes, que debieron haberse levantado entre 1792 y 1794, a juzgar por una inscripción localizada en el dintel de la puerta de la escalera de caracol que sube al deambulatorio superior, y en la que sólo se consignan tales años sin más dato alguno, pero que es indicativa de que para entonces ya se contaba con este primer cuerpo del edificio. Por su estado de conservación y por análisis preliminares que se han hecho en los muros y contrafuertes ${ }^{56}$ puede afirmarse que la piedra utilizada en ellos es de bastante buena calidad, dado que al momento la estructura no presenta ningún deterioro de importancia; desafortunadamente no se localizaron indicaciones de los bancos de material de los cuales se extrajo dicha piedra.

La tercera etapa constructiva correspondería a la fábrica de la cúpula (foto 3) y presumiblemente ocurriría entre 1794 y 1795, a

55. Alejandro Topete del Valle, Aguascalientes. Guía para visitar la Ciudad y el Estado, edición del autor, Aguascalientes, 1968, p. 150.

56. J. Jesús López García, Documento del Proyecto de Restauración del Camarín de San Diego, Gobierno del Estado, Aguascalientes, 1996. 
juzgar por una nota del guardián del convento de aquella época, que a la letra dice:

En quatro de Agosto de 1795 sepuso la cruz del simborrio en el Camarín q esta haciendo asu costa sin alluda del convto. ni otra alguna persona, Dn Juan Franco Calera, Capitan y Sindico de este convto. a quien concedió el Rdo Definitorio por sus letras Patentes, como a Patrono segun las leyes de Castilla, entierro para sí, susesores, y parientes colaterales. ${ }^{57}$

Todo lo anterior nos plantea el hecho de que el lapso comprendido entre 1795 y 1797 se ocupó en dotar al edificio con el resto del ajuar eclesiástico (altares, ciprés, probablemente la fábrica de los retablos) y, suponemos, las imágenes que lo integran.

\section{La GEOMETRÍa Simbólica del Camarín}

En todo el período novohispano fue del todo común el hecho de que los frailes, los arquitectos, los alarifes, los artesanos y los artistas adoptaran diversos modelos para la creación de sus obras, que les eran asequibles a través de los grabados que les llegaban de la vieja Europa. En la Nueva España dichos modelos sufrían un proceso de adaptación a las condiciones de trabajo y de la mano de obra, y al espíritu y aspiraciones de los indígenas, que con frecuencia resultaban en (re)interpretaciones originales alejadas de sus correlatos de origen. En el campo de la edificación, los tratados de arquitectura europeos ejercieron una influencia de primer orden, al grado tal, que fue frecuente también la adopción de modelos de la arquitectura de la antigüedad clásica. Al respecto, Virginia Tovar Martín señala que:

Serlio, Vignola, Alberti, Palladio, Fontana, Vitrubio y otros, fueron autores cuyos tratados llegaron a manos de los maestros españoles y, a través de su

57. Fray Francisco Villalobos, citado por Ochoa, Op. cit., p. 30. 
consulta, les permitieron adquirir un conocimiento del clasicismo puro y ortodoxo, la ley de las proporciones, el empleo de los órdenes y un sentido arquitectónico libre, en cuyas premisas se fundamentaría el barroco. ${ }^{56}$

Y, como hemos visto, no sólo los maestros españoles, sino también los artistas, artífices y alarifes mexicanos; asimismo, no sólo de la tradición barroca, sino incluso la neoclásica.

De entre aquéllos, Serlio fue el primero y más difundido entre los maestros españoles, dado que "ningún tratadista del siglo XVI fue tan leído como él”, según sostiene Santiago Sebastián. ${ }^{59}$ Un ejemplo de la influencia de Serlio entre los maestros novohispanos lo fue sin duda el caso del arquitecto mexicano Francisco Guerrero y Torres, Maestro Mayor de la ciudad de México, quien diseñó y construyó la famosa Capilla del Pocito al pie del Cerro del Tepeyac entre 1777 y 1791, y quien, al decir de Marco Dorta, cierra "el brillante capítulo de la arquitectura mexicana del setecientos" ${ }^{60} \mathrm{Con}$ el estudio del Camarín de San Diego de Aguascalientes nos permitimos disentir de esta afirmación de Dorta: el monumento que nos ocupa no sólo cerraría ese "brillante capítulo" como arquitectura en general, sino como conclusión excelsa del subgénero "camarines" de la Nueva España.

Algunos de los dibujos reproducidos en el tratado serliano, correspondientes a monumentos de la antigüedad clásica, nos permiten conjeturar que muy probablemente el alarife Santiago Medina conoció el libro susodicho como fuente de inspiración para el diseño del Camarín de San Diego; hasta no es improbable que lo tuviera en su biblioteca particular, hecho no del todo ajeno entre los maestros no españoles, como lo demuestra el caso de Santiago Rosales, el "alarife mulato", quien tenía precisamente en su biblioteca un

58. Citada por Villegas en la Introducción al libro de Sebastián Serlio, Tercero y Cuarto Libro de Arquitectura (edición facsimilar), UAEM, México, 1978, p. 1.

59. Citado por Villegas en Serlio, Op. cit., p. 2.

60. Citado por Villegas, Ibid., p. 10. 
Serlio. ${ }^{61}$ Por lo demás, un hecho es altamente significativo en este contexto: como tendremos ocasión de detallar un poco más adelante, el diseño del Camarín está generado por la combinación de cuadrados y octágonos, solución de neta inspiración serliana según Villegas, ${ }^{62}$ si bien esta tradición llegó simplificada en el siglo XVIII a Toluca, en la sacristía franciscana de Felipe de Ureña, lo que de paso refuerza nuestra hipótesis de la relación entre la escuela de este último personaje y Santiago Medina, en tanto que debilita aparentemente la hipótesis de Tresguerras como posible influencia de nuestro alarife, aunque, como hemos visto, ni una ni otra son excluyentes, como lo sugiere la siguiente cita de Villegas, quien afirma que "Con el tratado de Serlio comienza el tipo de tratado didáctico, profusamente ilustrado, aceptable para constructores formados en el gremio y para eruditos", ${ }^{6}$ esto es, ideal para alguien como Felipe de Ureña y como Eduardo Tresguerras. Como se ve, pues, los tratados de arquitectura no fueron privativos de la tradición barroca ni de la tradición neoclásica; antes bien, vinieron a apuntalar la fase de transición entre una y otra, pues como tuvimos ocasión de señalar, la oposición nunca fue en la provincia tan ruda como se pretendía, ni tampoco fue ignorada sin más, sino todo lo contrario: se produjeron fórmulas híbridas y conciliadoras, de entre las cuales el Camarín de San Diego es un caso excelso.

\section{El modelo del Panteón Romano}

El diseño del Camarín, solucionado con la combinación de cuadrados y octágonos, es por tanto de clara inspiración serliana. Un examen somero del perfil interior de la planta del recinto nos permitió sospechar que probablemente Santiago Medina tomó como modelo el

\footnotetext{
61. Ibid., p. 15.

62. Ibid., p. 11.

63. Ibid., p. 12 (cursivas nuestras).
} 
perfil interior del Panteón de Agripa -monumento ampliamente ilustrado y descrito por Serlio en su libro-, si no fielmente, cuando menos sí de manera muy aproximada. Nuestro análisis posterior demostró que efectivamente el sistema de proporción y de trazo geométrico de la planta del Camarín es el mismo que el de la planta interior del Panteón Romano (figura No.1), ${ }^{64}$ no obstante que no hay una correspondencia total entre todos sus elementos, lo que indica que $\mathrm{Me}-$ dina tuvo el cuidado de no caer en la estéril copia, sino que reinterpretó el modelo de acuerdo con las necesidades, el programa y las dimensiones relativas del edificio, en eso sí, muy diferentes a las del gran monumento clásico.

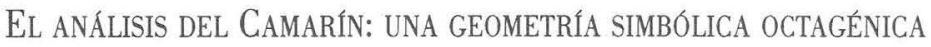

Sobre proyecciones ortogonales del edificio, en plantas y alzados, se construyeron sucesivamente diversas figuras geométricas que correspondieran con elementos arquitectónicos, decorativos o iconográficos fundamentales. A su vez, se aplicó el sistema de simetría dinámica de Hambidge, basado en rectángulos radicales de diversa índole; igualmente, se construyeron figuras geométricas derivadas de los polígonos regulares antes descritos, y se buscaron relaciones proporcionales a través de los números $\varphi$ (phi) y $\theta$ (theta) con sus correspondientes figuras geométricas (rectángulos áureos, compás áureo de tres y cuatro puntas, octágono estrellado). De todos los procedimientos utilizados, los que tuvieron una mayor significación en la composición del monumento fueron los relacionados con el octágono regular (generado por cierto con dos cuadrados girados a $45^{\circ}$ uno respecto del otro, solución "netamente serliana"), el octágono estrellado, el cuadrado dividido en cuadrados y rectángulos

64. Debemos enteramente el modelo de trazo del Panteón al Dr. Carlos Chanfón Olmos. Nuestra aportación consistió en sobreponerlo a la planta del Camarín, relacionando sus ejes y trazos con sus equivalentes en el monumento. 


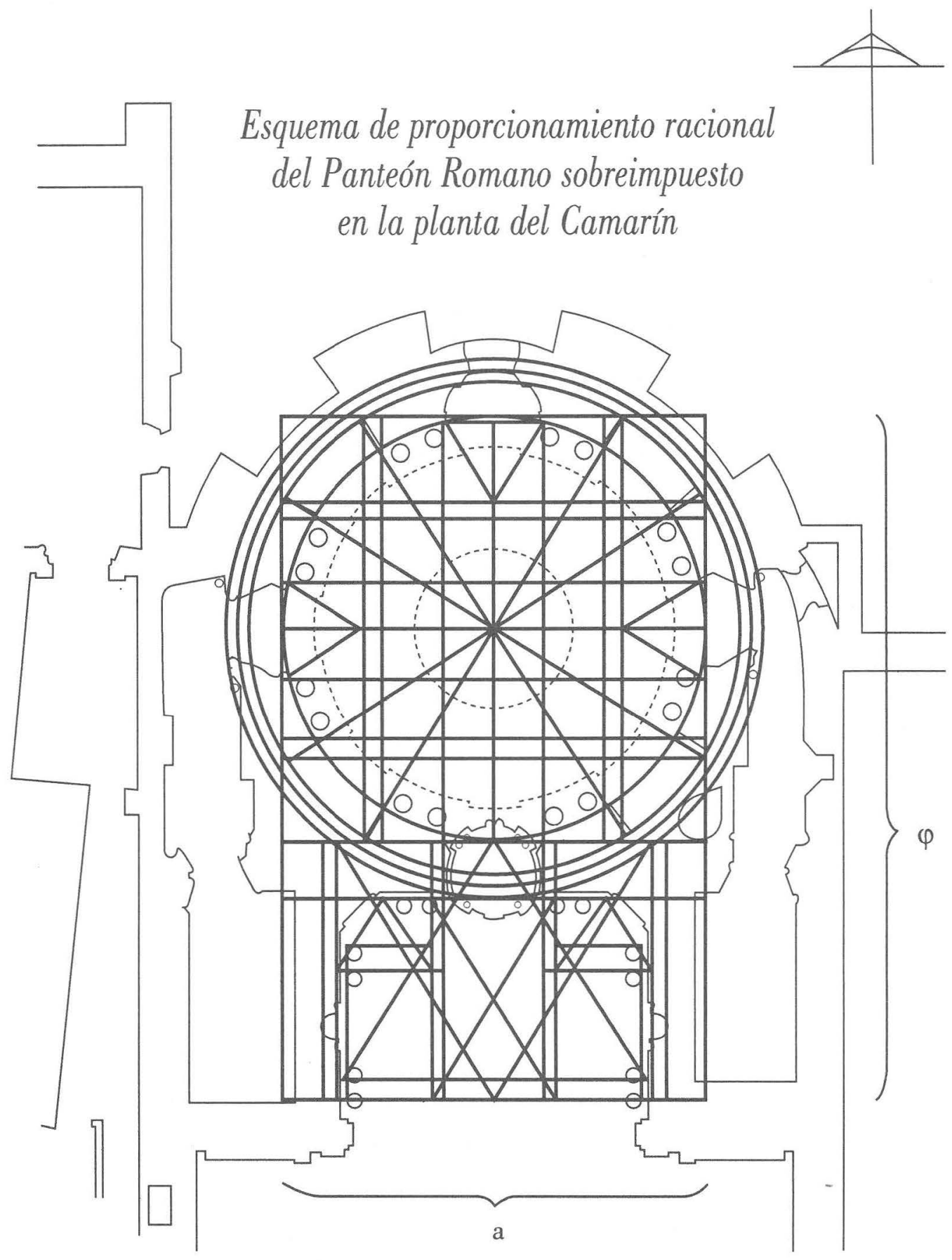


áureos menores, generado a su vez por el compás áureo de tres y cuatro puntas y, por ende, los números $\varphi$ y $\theta$, entre cuyas figuras geométricas, derivadas de estos números irracionales, existen estrechos vínculos determinados por las propiedades aditivas de sus progresiones geométricas. También pudo detectarse la cerrada relación entre la geometría y el número 8 y sus múltiplos y submúltiplos, que se corresponden todos con la simbología religiosa de la iconografía del Camarín: cuatro Doctores de la Iglesia, cuatro Evangelistas, cuatro miembros de la familia de la Virgen, treinta y dos símbolos de la letanía lauretana, cuatro santos y cuatro venerables relacionados con la devoción y el dogma de la Inmaculada, ocho figuras angélicas (arcángeles y ángel guardián), dieciséis angelillos. Luego de someter el monumento a los procedimientos sucesivos previamente indicados, se pudo concluir que la geometría simbólica del Camarín obedece a un plan octagénico (figura No. 2), “...que se detalla en el cuadro de la página 47:

De acuerdo con lo anterior, se puede concluir que en lo que toca al análisis geométrico la empresa fue exitosa al comprobarse que, efectivamente, tal como se había hipotizado, se verificó un sistema de proporción armónica como estructura esencial que rige la belleza del edificio, cuyos trazos están determinados a su vez por dos razones o números irracionales estrechamente vinculados: los ya citados $\varphi$ (phi, o número de oro) y $\theta$ (Theta).

Dichos números o razones armónicas se generaron a partir, respectivamente, del compás áureo de tres y cuatro puntas, y del octágono estrellado, que por cierto rige la composición tanto en planta como en alzado, y que es posible obtener por la "combinación de cuadrados y octágonos" (dos cuadrados girados entre sí $45^{\circ}$ dan por resultado un octágono, como la solución serliana). De hecho es posible generar el octágono a partir del patrón de cuadrados y rectángulos áureos, y lo que es más, al segmentar dicho octágono en sucesivas configuraciones estelares de ocho puntas (octágonos estrellados), cada vez mayores, su crecimiento a partir de un centro 


\section{Equema de la Geometría Simbólica del Camarín de la Virgen}

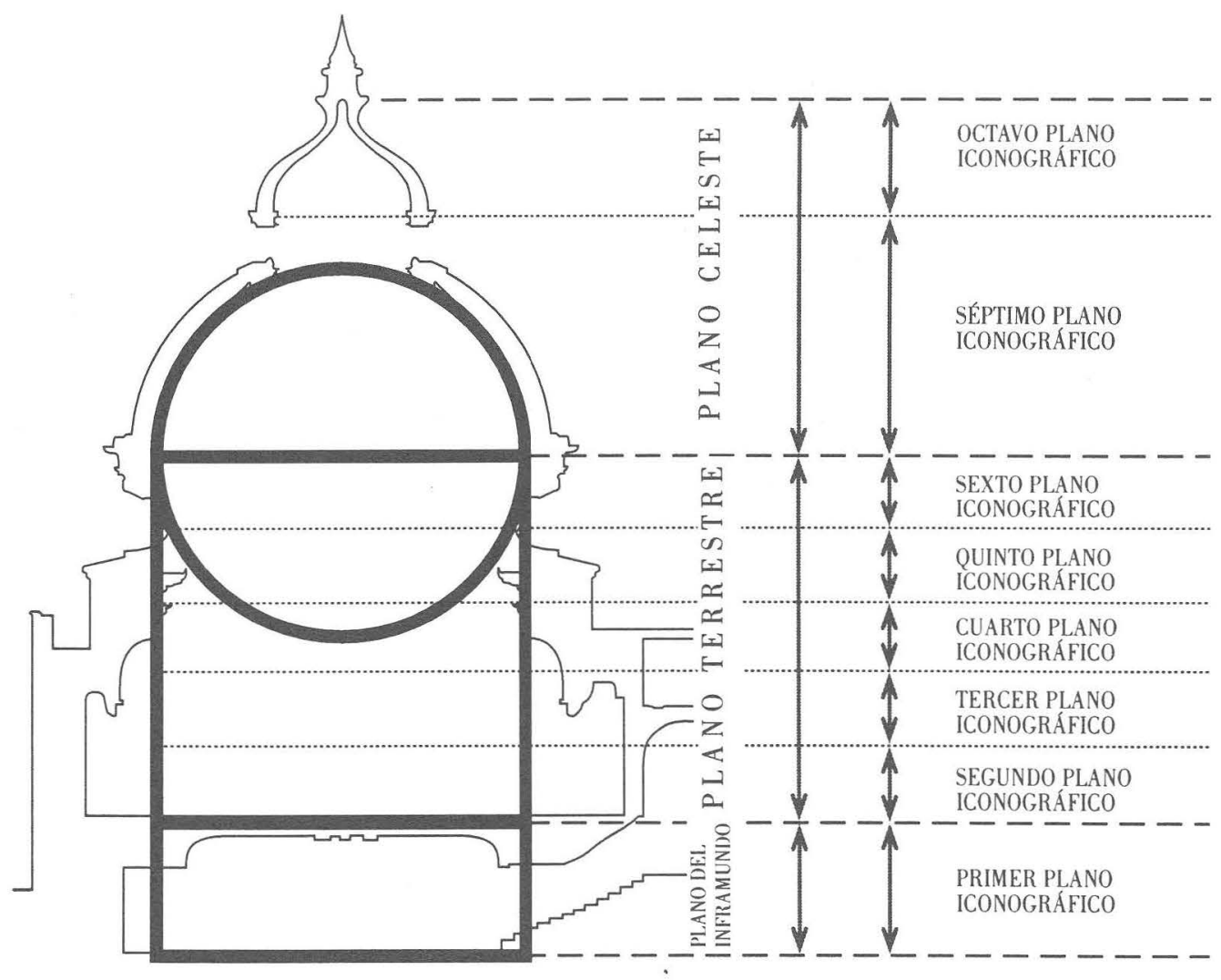




\begin{tabular}{|c|c|c|c|}
\hline PLAN ESPACIAL & \multicolumn{3}{|c|}{ PLAN ICONOGRÁFICO } \\
\hline $\begin{array}{l}\text { Pimer Plano Espacial: } \\
\text { Plano del Inframundo }\end{array}$ & $\begin{array}{l}\text { Primer Plano } \\
\text { Iconográfico }\end{array}$ & $\begin{array}{l}\text {-Santos varones } \\
\text { (Frailes difuntos) }\end{array}$ & $\begin{array}{l}\text { Ocho } \\
\text { Vanos }\end{array}$ \\
\hline \multirow{7}{*}{$\begin{array}{l}\text { Segundo Plano Espacial: } \\
\text { Plano Terrestre }\end{array}$} & $\begin{array}{l}\text { Segundo Plano } \\
\text { Iconográfico }\end{array}$ & $\begin{array}{c}\text {-Familia de la Virgen (San Juan } \\
\text { Bautista, San José, San Joaquín, } \\
\text { Santa Ana) } \\
\text {-La Inmaculada, Letanía } \\
\text { Lauretana y Reyes Fundadores } \\
\text { (San Luis Rey de Francia, } \\
\text { Sta. Isabel de Hungría) }\end{array}$ & $\begin{array}{c}\text { Cuatro } \\
\text { Imágenes } \\
\text { Cuatro } \\
\text { Vanos }\end{array}$ \\
\hline & $\begin{array}{l}\text { Tercer Plano } \\
\text { Iconográfico }\end{array}$ & -Príncipes y Ángel Guardián & $\begin{array}{l}\text { Ocho } \\
\text { Imágenes }\end{array}$ \\
\hline & $\begin{array}{l}\text { Cuarto Plano } \\
\text { Iconográfico }\end{array}$ & $\begin{array}{l}\text {-Evangelistas (San Mateo, San } \\
\text { Marcos, San Lucas, San Juan) }\end{array}$ & $\begin{array}{l}\text { Cuatro } \\
\text { Imágenes }\end{array}$ \\
\hline & & $\begin{array}{c}\text {-Doctores (San Ambrosio, } \\
\text { San Agustín, San Jerónimo, } \\
\text { San Gregorio) }\end{array}$ & $\begin{array}{l}\text { Cuatro } \\
\text { Imágenes }\end{array}$ \\
\hline & $\begin{array}{l}\text { Quinto Plano } \\
\text { Iconográfico }\end{array}$ & $\begin{array}{l}\text {-Mongíbelos o Ángeles } \\
\text { Ceriferarios }\end{array}$ & $\begin{array}{l}\text { Dieciséis } \\
\text { Imágenes }\end{array}$ \\
\hline & $\begin{array}{l}\text { Sexto Plano } \\
\text { Iconográfico }\end{array}$ & $\begin{array}{l}\text {-Venerables (Sutil Escoto, } \\
\text { V. Padre Ceres, V. Padre } \\
\text { Cornelio, V. Madre Agreda) }\end{array}$ & $\begin{array}{l}\text { Cuatro } \\
\text { Imágenes }\end{array}$ \\
\hline & & $\begin{array}{l}\text {-Santos (San Juan Damasceno, } \\
\text { San Gregorio Nacianceno, San } \\
\text { Alberto Magno, Santa Teresa) }\end{array}$ & $\begin{array}{l}\text { Cuatro } \\
\text { Imágenes }\end{array}$ \\
\hline \multirow[b]{2}{*}{$\begin{array}{l}\text { Tercer Plano Espacial. } \\
\text { Plano Celeste }\end{array}$} & $\begin{array}{l}\text { Séptimo Plano } \\
\text { Iconográfico }\end{array}$ & -Símbolos marianos (?) & (?) \\
\hline & $\begin{array}{l}\text { Octavo Plano } \\
\text { Iconográfico }\end{array}$ & Ángeles (“Ave María”) & $\begin{array}{l}\text { Ocho } \\
\text { Imágenes }\end{array}$ \\
\hline
\end{tabular}

65. Cabe hacer notar que la fiesta de la Inmaculada es precisamente el 8 de diciembre, cerrando así el simbolismo religioso alrededor de este número. Asimismo, las palabras "Ave María" suman un total de 8 letras. 
está determinado por progresiones geométricas definidas por el número de oro en sentido ortogonal, y por el número theta en el sentido de las direcciones indicadas por las puntas de las estrellas formadas (figura No. 3). ${ }^{66}$ Esto es lo que György Doczi denomina dinergía, que es la "energía creativa de crecimiento orgánico" que subyace a las formas del reino animal y vegetal, y hasta del arte y la arquitectura. $^{6 ?}$

$Y$ estos dos patrones de proporcionamiento están a la base del trazo geométrico de la planta del Panteón de Agripa en Roma, lo que nos permite afirmar que Santiago Medina lo tomó como modelo para la planta del Camarín de San Diego, z incluso lo adecuó también para el alzado. Muy probablemente la solución la decantó Medina o a través de la influencia de Francisco Eduardo Tresguerras, o a través de la escuela de Felipe de Ureña, lo que de cualquier modo nos remite al tratado de Sebastián Serlio. Las razones armónicas encontradas, además, se verificaron tanto independientes entre sí como perfectamente vinculadas, lo que es un indicador de sus propiedades aditivas y, por ende, revela el uso de progresiones geométricas entre las partes del monumento y entre éstas y el todo, dotándolo del orden y la belleza única que lo caracteriza.

Hemos comprobado, también, que los números a la base de las figuras geométricas generadoras del edificio (el cuadrado y el octágono), es decir, los números 4 y 8 , y los números 16 y 32 , se relacionan con la iconografía, con la iconología y con la disposición espacial de las imágenes o iconogesia, lo que nos permite afirmar que existe también una relación de mutua determinación entre el tema iconológico y el tema armónico del monumento.

66. Todos los gráficos son calcas de los planos a escala elaborados para el proyecto de restauración del Camarín, a cargo del M. en Arq. Jesús López García, y han sido cotejados con los planos del Arq. Francisco Aguayo Mora. Los trazos sobre estco gráficos son aportación nuestra.

67. Cfr. György Doczi, The Power of Limits. Proportional Harmonies in Nature, Art, and Architecture, Shambhala, Boston \& London, 1994, p. 3. 


\section{CONCLUSIONES GENERALES}

La investigación cuyos resultados hemos expuesto ha demostrado que en la base de la concepción del Camarín de San Diego radica un complejo entramado armónico dado por la utilización del octágono como figura geométrica básica, y de los números $\varphi$ y $\theta$ como estructura racional y relacional generadora de las dimensiones relativas (esto es, de todo el sistema de proporcionamiento); pero este complejo patrón geométrico tenía que ser ubicado como un hecho histórico -mutable-, con el riesgo de que evitarlo como tal, implicaba perder una extraordinaria oportunidad para comprender su significado pleno.

En este sentido, el examen riguroso del monumento, en lo que atañe a los procedimientos analíticos propios de la geometría y la iconología, nos ha permitido pues llegar a la conclusión general de que la proporción y la simbología del Camarín están tejidas alrededor de un sólo y mismo tema armónico e iconológico, es decir, el monumento fue concebido con una geometría simbólica y trascendente, octagénica y dinérgica, cuyo trazo y perfección matemática, según los códigos de significación novohispanos, no eran sino la concreción misma del ideal mariano, particularmente en la advocación inmaculista: la pureza del trazo (el Camarín como una hermosa flor, la más pura, con un patrón de crecimiento matemático perfecto) de hecho era interpretada como producto de una revelación divina, de modo que para el común de los mortales no implicaba preocupación alguna cuestionarse sobre las bases racionales de semejante revelación; ésta era cuestión de fe y no de raciocinio; era, en los códigos novohispanos, parte de la vida misma, la realidad presente, vivida, sin mediación alguna de la razón. Pérez Gómez apoya nuestro argumento cuando afirma que en el período barroco "el orden denotado por la regularidad matemática o geométrica, percibido a través de la observación de la Naturaleza divina, era el signo más inmediato de la revelación natural que mostraba la participación 
de Dios en la realidad humana y, consecuentemente, garantizaba su significado". 68

Concluimos por tanto que en el Camarín se observa una equilibrada relación entre el simbolismo dominante, propio de la piedad dieciochesca, y la solución geométrica, conviviendo y coexistiendo armónicamente, sin conflicto; antes bien, la proporción y el símbolo en el Camarín derivan, como lo hemos demostrado en los respectivos análisis, de lo que podría denominarse un solo y mismo principio ordenador: al desplegar una estructuración creciente basada en el octágono estrellado, y por ende en los números irracionales antes citados, el Camarín presenta un trazo que a su vez es manifestación simbólica de la perfección y la inmaculada pureza que la tradición cristiana atribuye a la advocación mariana de San Diego. Su desarrollo espacial, perfectamente controlado por las relaciones proporcionales del número de oro y del número theta, se desenvuelve de acuerdo con un incremento progresivo que conserva los mismos patrones de crecimiento dinérgico de las plantas y los seres vivos. Es este principio de conocimiento fundamental de las formas armónicas de la naturaleza o de la "realidad vivida", asociado simbólicamente en tanto atributo religioso y divino con las virtudes de la Inmaculada, lo que recarga de significado al Camarín de San Diego. De esta manera, en la solución dada al edificio hemos constatado lo que Pérez Gómez ha dicho del barroco europeo, es decir, encontramos una síntesis conciente y no contradictoria entre las dimensiones racional (esfera conceptual) y de la experiencia (esfera perceptual).$^{69}$

En consonancia con lo anterior, concluimos también que el maestro alarife Santiago Medina encarnó y concilió en una síntesis asombrosa las dos tradiciones aparentemente opuestas que lo alimentaron: la barroca de la escuela de Felipe de Ureña, de clara

68. Pérez Gómez, La Génesis y Superación...., Op. cit., p. 181.

69. Ibid. 
concepción patrimonialista, subsidiaria de la piedad dieciochesca, y la neoclásica influenciada por Tresguerras, de claro carácter regalista. Así, en Medina, la conciliación de estos opuestos se dió de manera suave, sin saltos bruscos; antes bien, subrayó la continuidad más que la ruptura del simbolismo barroco. Esto fue posible por las condiciones históricas específicas de la villa de Aguascalientes y su sociedad, que seguía estando fuertemente influida por la concepción pietista, pero también determinada por los problemas y obstáculos que la Corona encontró en las nuevas intendencias para imponer la reforma administrativa de la Casa de los Borbones.

En el campo de la construcción los gremios no desaparecieron por completo y por ende las formas de organización del trabajo y las formas del trabajo mismo siguieron adscritas a la estructura gremial en el interior de la Nueva España. Con todo, Santiago Medina pareció comprender las ventajas de operar al margen de los gremios -sin abandonar por ello totalmente sus enseñanzas- y debió percibir el nuevo estatus que su capacidad y su ingenio le conferían en una sociedad poco dada a valorar a las gentes de origen indígena (a no ser por sus extraordinarias capacidades, que podían darle carta de presentación y prestigio entre los notables, tal y como lo demuestra la confianza depositada en Santiago Medina por la familia Calera, y en particular por Pedro Manuel y más tarde por Juan Francisco, al nombrarlo como perito valuador en el primer caso, y como constructor del Camarín en el segundo). Sus habilidades como maestro alarife debieron trascender las fronteras estrictamente locales hasta alcanzar a codearse y/o asesorarse con gentes de la talla de Tresguerras, en el reducido margen de movimiento representado por toda la franja del bajío guanajuatense.

Por otra parte, relacionado con esto último, el estudio de este extraordinario recinto nos ha permitido constatar las relaciones estilísticas entre las villas de Santa María de los Lagos y la de Aguascalientes, encontrando fuertes vínculos no sólo por su historia común, si- 
no por los rasgos que algunos de sus monumentos presentan, claves para la reconstrucción de la historia de la arquitectura regional del período. En efecto, Lagos y Aguascalientes comparten la fase final del desarrollo del barroco estípite y manifiestan incluso los primeros atisbos de una arquitectura en transición al neoclásico; diversos monumentos atestiguan las huellas de una misma escuela de canteros y de maestros alarifes, como es el caso, en Aguascalientes, de Gregorio Reyes y del mismísimo Santiago Medina, de quien puede decirse que si bien no ha sido posible probar su presencia en la villa de Lagos, sin embargo, es evidente que varios de los rasgos de la arquitectura laguense lo influenciaron de manera categórica. En la agenda de investigación ha quedado pendiente el origen de Santiago Medina, dado que no fue localizado en los registros y partidas de bautismo de indios de los libros correspondientes del Archivo Parroquial de Lagos. Lo que sí queda plenamente probado es su autoría material e intelectual en la obra del Camarín de San Diego, sin menoscabo alguno de las influencias que pudieron haberlo formado -léase Tresguerras, Tolsá o Felipe de Ureña-; el extraordinario manejo del espacio y de la proporción, la concepción matemática rigurosa y el dominio de la simbología hacen de Santiago Medina un personaje singular, más allá de cualquier intención panegírica, cuyas destrezas y conocimientos -fueran prácticos o académicos- debieron haberle otorgado, como dijimos, una situación de privilegio y respeto en la cerrada sociedad aguascalentense de aquellos tiempos. Así, la trayectoria personal de Santiago Medina condensa, en más de un sentido, las vicisitudes de la sociedad novohispana en el azaroso tránsito del patrimonialismo barroco al regalismo neoclásico. El Camarín de San Diego, por su insólita solución, en la que conviven armónicamente ambas tradiciones, se convierte por tanto en un monumento extraordinariamente atípico y probablemente único por su concepción híbrida, soportada por una geometría perfecta y un simbolismo sutil, que le otorgan el estatus de belleza que todos señalan. 
